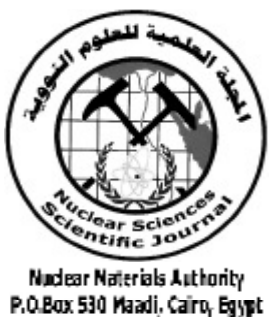

ISSN 2314-5609

Nuclear Sciences Scientific Journal

6, $71-91$

2017

http://www.ssnma.com

\title{
GEOLOGY, GEOCHEMISTRY AND RADIOACTIVITY OF THE MONZOGRANITE ROCKS, NORTH WADI GHADIR, SOUTH EASTERN DESERT, EGYPT
}

\author{
FARRAGE M. KHALEAL; MOHAMED S. KAMAR and ANAS M. EL-SHERIF \\ Nuclear Materials Authority
}

\begin{abstract}
Wadi Ghadir area show different types of the basement rocks such as; ophiolitic mélange, metabasalt, quartz-diorite, granodiorite and monzogranite. The fresh monzogranite suffered in elsewhere alteration processes and rich in sulphide minerals. The studied monzogranite has peraluminous character, alkaline affinity, emplaced in within plate setting and crystallized under low water vapour pressure $(2-3 \mathrm{~Kb})$ and temperature $\left(760-800^{\circ} \mathrm{C}\right)$. The propylitic and $\mathrm{K}$-metasomatism are the main alteration types in the studied altered monzogranite, while plagioclase destructed and formed epidote. The identified heavy minerals are mostly pyrite, sphalerite, galena, monazite, hematite and goethite.

Mineral chemistry by EPMA analyses exhibit that pyrite mineral is rich in Co and Se and low values of $\mathrm{Mn}$ and $\mathrm{Cu}$.

The radioactivity increases toward the more acidic rocks, from granodiorite to altered monzogranite. The average eU content indicates that the fresh monzogranite is not uraniferous, while the altered monzogranite is uraniferous.
\end{abstract}

\section{INTRODUCTION}

The studied area is located between the lat. $24^{\circ} 49^{\prime}$ and $24^{\circ} 53^{\prime} \mathrm{N}$ and the long. $34^{\circ} 51^{\prime}$ and $34^{\circ} 56^{\prime} 40^{\prime \prime} \mathrm{E}$, at the northern part of Wadi Ghadir (Fig. 1) lying at about $20 \mathrm{~km}$ south of Marsa Alam City. The older granites have been referred as gray granites (Hume 1935; El-Ramly and Akaad 1960), syn- to late-orogenic plutonites (El-Shazly 1964), syn-orogenic granites (El-Gaby 1975), and G1 granites (Hussein et al. 1982). They were emplaced around 930-850 Ma ago and possibly extended to 711 Ma (El-Manharawy 1977; Hashad 1980; Dixon 1981; Stern and Hedge 1985; Hassan and Hashad 1990). The younger granites comprise the intrusive granitic rocks referred to in the same nomenclature given by El-Ramly and Akaad (1960) and Akaad and Noweir
(1980) and as late orogenic plutonites (ElShazly 1964). Wadi Ghadir ophiolite is one of the best preserved sections through late Proterozoic upper oceanic crust anywhere in the world (Kröner et al. 1992). The ophiolite of Wadi Ghadir area comprises ultramafic rocks, gabbroic rocks, sheeted dikes and pillowed basalts (El-Sharkawy and El-Bayoumi 1979; Basta 1983). El-Sharkawy and El-Bayoumi (1979) classified the rocks that crop out along the eastern Ghadir as granites belonging to the older and younger (Gattarian) granites.

Takla et al. (1992) classified the granitoids of Wadi Ghadir as (a) diorites and granodiorites, which have similar characteristics to the older granites and (b) the younger granites that have similar characteristics to the alkalic and other anorogenic granitic suits. 


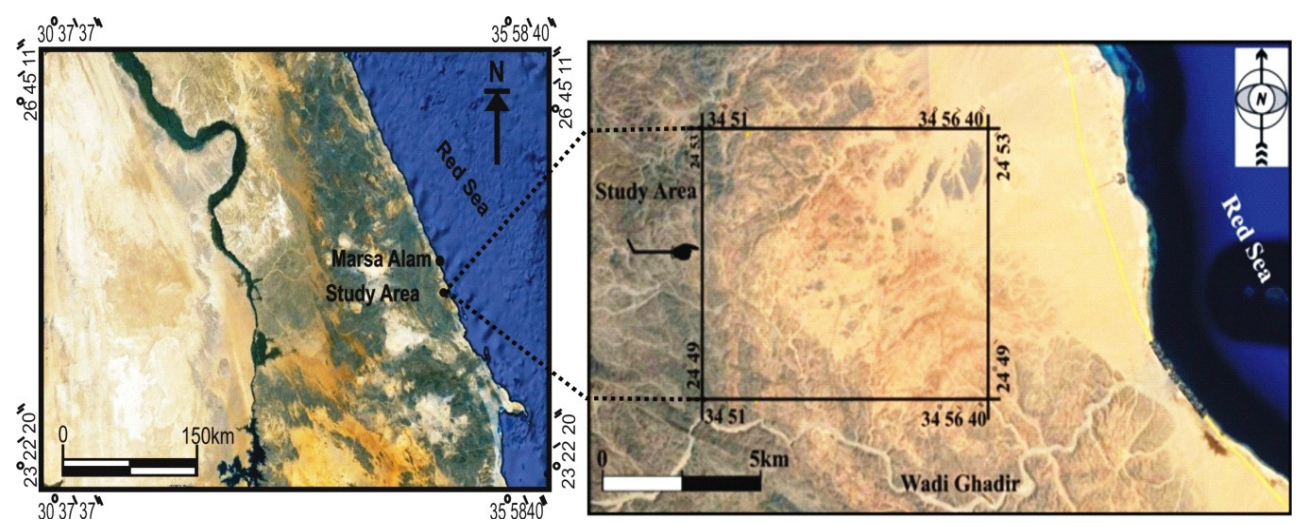

Fig. 1: Landsat image showing location of the study area

Ibrahim and Ali (2003) studied the granitic rocks in Wadi Ghadir area; South Eastern Desert, Egypt and the occurrence of secondary uranium minerals. The authors are subdivided the granitoid rocks in the Ghadir area according to their field relationships, petrography and geochemical characteristics into two types of magmatic cycles. The first magmatic cycle (include quartz diorite and gneissose granodiorite), which have a metaluminous character and were emplaced during pre-plate collision regime under high water-vapor pressure (3$7 \mathrm{~Kb})$ and temperature $\left(800-840^{\circ} \mathrm{C}\right)$. The second magmatic cycle is represented by perthitic leucogranite and two mica (muscovite-biotite) granites and was emplaced during syncollision at moderate water-vapor pressure (1$3 \mathrm{~Kb})$ and temperature $\left(760-800^{\circ} \mathrm{C}\right)$.

Ali and Lentz (2011) studied the mineralogy, geochemistry and age dating of the shear zone hosting Nb-Ta, Zr-Hf, Th and U-bearing granitic rocks in the Ghadir and El-Sella areas, South Eastern Desert, Egypt. The authors were concluded that the mineralization in the Ghadir shear zone, represented by betafite, Uminerals (uraninite and uranophane), Hf-Zircon, monazite, xenotime, and rutile. Field evidence, textural relations, and the composition of ore minerals suggest that the main mineralizing event was magmatic (615+/-7 CHIME monazite).
Kamar (2015) studied the geology, geochemistry and mineralization of the basement rocks exposed in Wadi Ghadir and classified the studied rocks into quartz diorites, monzogranites, and pegmatites. The pegmatites are classified into zoned pockets and zoned lenses (fractured) pegmatites. The zoned pegmatite pockets have gradational contacts with its host monzogranites and have the following zonal arrangement: border, intermediate, and core zones. The monzogranite and the border zone pegmatite have peraluminous to slightly metaluminous characteristic, calc-alkaline to alkaline affinity, emplaced in volcanic arc setting, and crystallized under moderate water-vapor pressure $(3-5 \mathrm{~kb})$ and temperature of $800-850^{\circ} \mathrm{C}$ for monzogranites and $700-750{ }^{\circ} \mathrm{C}$ for border zone pegmatite. $\mathrm{He}$ added that the identified heavy minerals are classified into several groups according to their anion groups either they are radioactive or non radioactive: (1) silicate mineral (thorite), (2) carbonate mineral (bastansite), (3) fluoride mineral (fluorite), (4) oxide minerals (columbite and hematite), (5) sulfide mineral (pyrite), and (6) hydroxide minerals (goethite and illite).

The present study aims to describe the geology, petrography, and geochemistry of the monzogranite and focuses on the mineralization associated with altered monzogranite. 


\section{METHODS OF STUDY}

Fifteen samples ( 5 from granodiorite, 7 from monzogranite and 3 from the altered monzogranite) were chemically analyzed. Major oxides were performed by conventional wet chemical techniques, while trace elements were determined by X-ray fluorescence technique (XRF) using PHILIPS X'Unique II instrument. Mineral chemistry were determined on the JEOL JXA-733 Superprobe; operating conditions were $15 \mathrm{kV}$, with a beam current of $50 \mathrm{nA}$ and peak counting time was $30 \mathrm{sec}-$ onds for all elements. The standards used are Marc (for $\mathrm{S}$ and $\mathrm{Fe}$ ), $\mathrm{In}_{2} \mathrm{Se}_{3}$ (for $\mathrm{Se}$ ), CoMet (for $\mathrm{Co}$ ), MnMet2 (for $\mathrm{Mn}$ ), CuMet2 (for $\mathrm{Cu}$ ) and AgMet (for Ag).

The concentration of equivalent uranium (eU) in ppm, equivalent thorium (eTh) in ppm, radium $(\mathrm{Ra})$ in ppm and potassium $(\mathrm{K})$ in \% were determined using multi-channel analyzer Gamma ray spectrometric technique using a Bicron Scintillation Detector NaI (TL) $76 \mathrm{x}$ $76 \mathrm{~mm}$.

The heavy minerals were separated using heavy liquid (bromoform) separation technique, then passed through the Frantz isodynamic separator to produce several magnetic fractions and then the heavy minerals were picked under the binocular microscope. X-ray diffraction technique (XRD) was used to identify the unknown minerals using PHILIPS PW $3710 / 31$ diffractometer.

The mineralogical, chemical and radiometric analyses were carried out at the laboratories of the Nuclear Materials Authority, (NMA). The mineral chemistry was carried out at the Microscopy and Microanalyses Facility, University of New Brunswick (UNB), Fredericton, New Brunswick, Canada.

\section{GEOLOGIC SETTING}

Wadi Ghadir area (Fig. 2) include ophiolitic mélange, metabasalt, quartz-diorite, granodiorite and monzogranite.

The ophiolitic mélange located in the southwestern part of the mapped area. The mélange is divided into two facies, proximal and distal, according to the source of its ophiolitic components. The proximal facies is composed of fragmented rock-debris in a matrix of schistose mudstones that abound in blocks of serpentinized peridotite, many of which are surrounded by talc-carbonate rock. The dis-

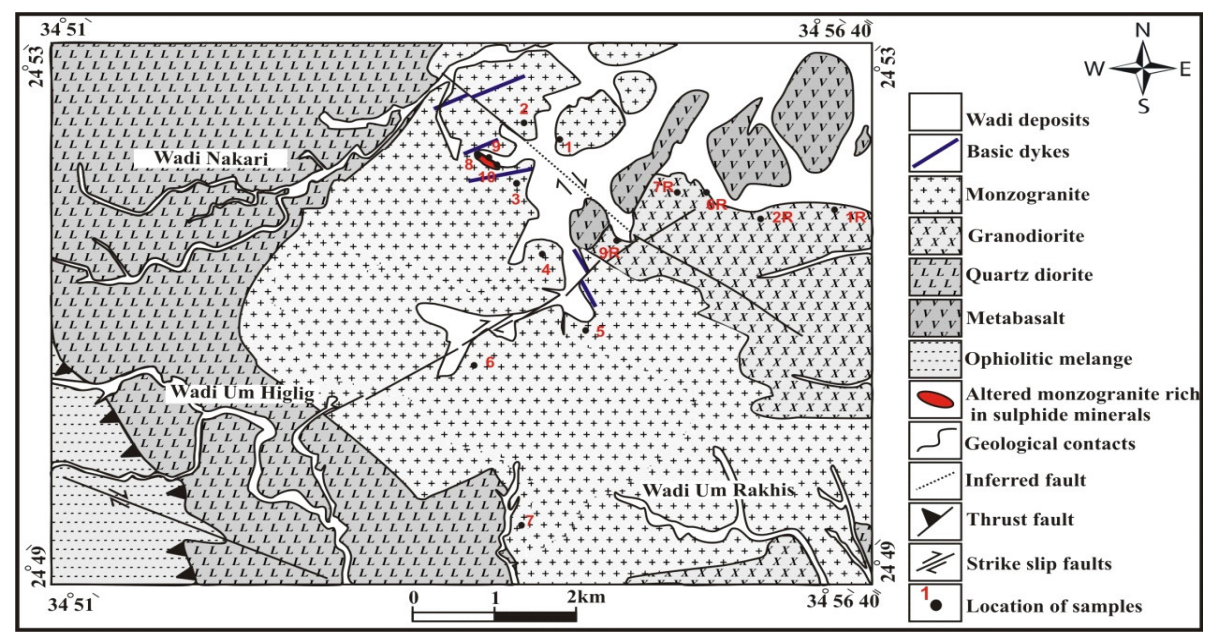

Fig. 2: Geologic map of the study area (Modified after Takla et al., 1992) 
tal facies is composed of low-grade pelitic schists that bear pebbles of other rock types.

Metabasalt located in the northeastern part of the mapped area (Fig. 2) and characterized by highly fractured and joints. It is intruded by quartz-diorite, granodiorite and monzogranite with sharp contacts. El-Bayoumi (1980) suggested that Wadi Ghadir basalts are more differentiated than typical MORB and believed that they are plume basalts which originated from stratified and enriched low velocity zone at the initiation of spreading.

Quartz diorite covers a considerable area especially in the western part of the mapped area (Fig. 2). The rock is medium- to coarsegrained with grayish green colour and form moderate relief mountains and suffered intensive jointing of different directions producing easily weathered surfaces. It is intruded by the granodiorite and monzogranite rocks with sharp intrusive contacts. The quartz-diorite is structurally thrusted by ophiolitic mélange along the fault which strikes $45^{\circ}$ and dipping $20^{\circ} \mathrm{SE}$.

Granodiorite covers a considerable area (Fig. 2) especially in the south and eastern part of the mapped area and is intruded by monzogranite. The rock is medium- to coarsegrained, grey to dark grey in colour and show cavernous, exfoliation and block weathering. The granodiorite is frequently hosted mafic microgranular enclaves. These enclaves attain variable dimensions (few $\mathrm{cms}$ to $25 \mathrm{~cm}$ of long axes) and variable shapes ranging from subrounded, oval and elongated to irregular forms.

Monzogranite covers a huge part in the mapped area (Fig. 2) and it is medium- to coarse-grained and whitish- to reddish-pink in colour. It is medium to high relief mountain terrains and cut by basic dykes. It shows cavernous and exfoliation weathering and are characteristically highly jointed and fractured. Many of these joints are filled by copper mineralizations and/or pegmatite veins and bodies.
Altered monzogranite is fine- to mediumgrained, reddish in colour and enriched in sulphide minerals, which can be seen by naked eye. There is a high alteration product represented by hematization and record abnormal radioactivity (Fig. 3).

The all exposed rocks cut by a number of right lateral strike slip faults striking NE-SW and NW-SE.

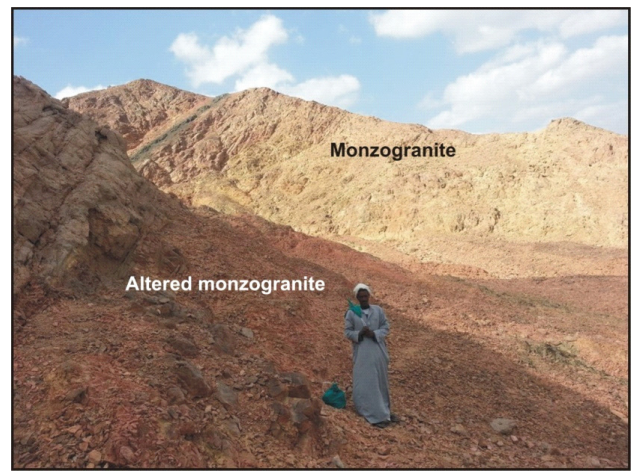

Fig. 3: Altered monzogranite rich in sulphide minerals, Looking $\mathrm{N}$

\section{PETROGRAPHY}

Monzogranite is composed of K-feldspar, quartz, plagioclase, biotite and minor amounts of muscovite. Zircon, apatite, titanite and opaques are accessories. K-feldspars occur as subhedral to euhedral crystals, represented by orthoclase microperthite and microcline microperthite that occasionally stained by iron oxides (Fig. 4). Quartz forms subhedral to anhedral crystals and as interstitial grains between feldspar crystals. Plagioclase occurs as euhedral to subhedral elongated crystals and has albite to oligoclase composition $\left(\mathrm{An}_{8 \text { - }}\right.$ ${ }_{15}$ ), where exhibits albite and combined albite and pericline twinning. Plagioclase crystals may exhibit normal zoning and show selective saussuritization (Fig. 5). Biotite occurs as euhedral to subhedral elongate to flakey crystals and sometimes altered to chlorite and 


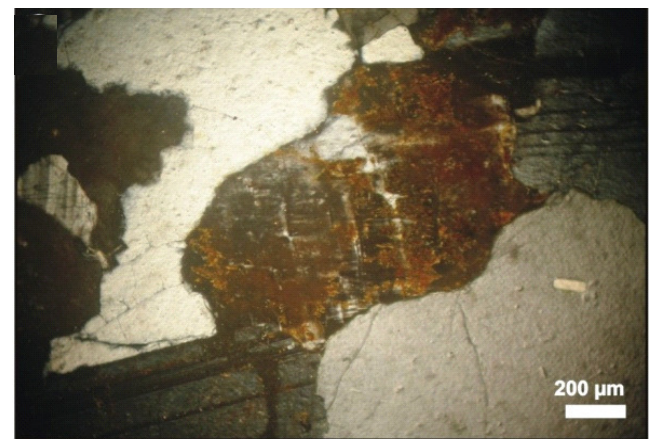

Fig.4: Photomicrograph showing microcline perthite stained by iron oxide in monzogranite, XPL

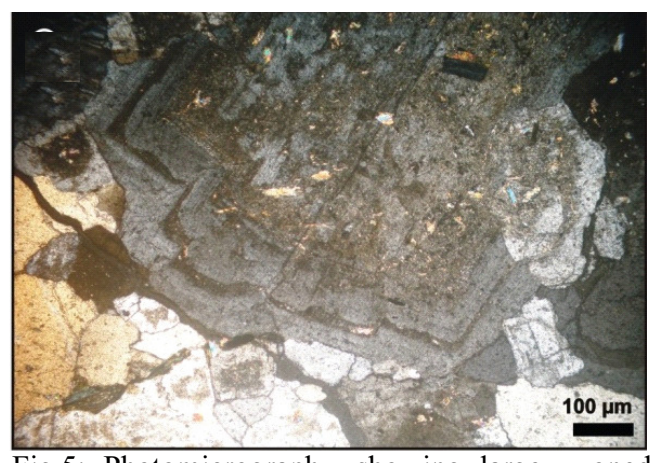

Fig.5: Photomicrograph showing large zoned crystal of saussuritized plagioclase in monzogranite, XPL

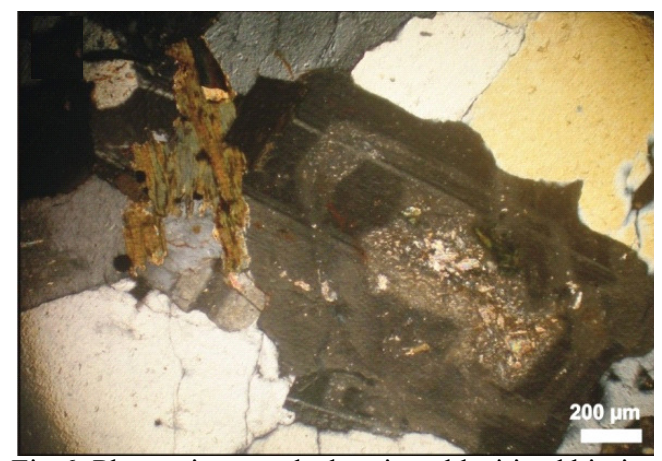

Fig.6: Photomicrograph showing chloritized biotite protruded the zoned saussuritized plagioclase in monzogranite, XPL protruding the zoned saussurite plagioclase (Fig. 6). The flakes can be enriched by iron oxides. Muscovite forms subhedral to anhedral flakey crystals which may fill the space between the major constituents and corroded by plagioclase (Fig. 7). Monazite occurs as dispersed grains associated with biotite and apatite (Fig. 8). Zircon occurs as euhedral to subhedral prismatic crystals and sometimes twinned, coated by iron oxides and may be included in the plagioclase (Fig. 9). It sometimes associated with muscovite, biotite and quartz (Fig. 10). Apatite occurs as euhedral prismatic crystals in association with biotite and monazite. Opaques form irregular patches

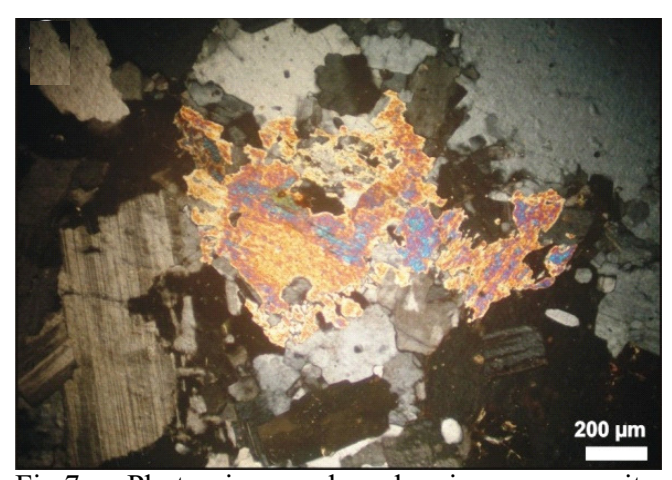

Fig.7: Photomicrograph showing muscovite corroded by plagioclase in monzogranite, XPL

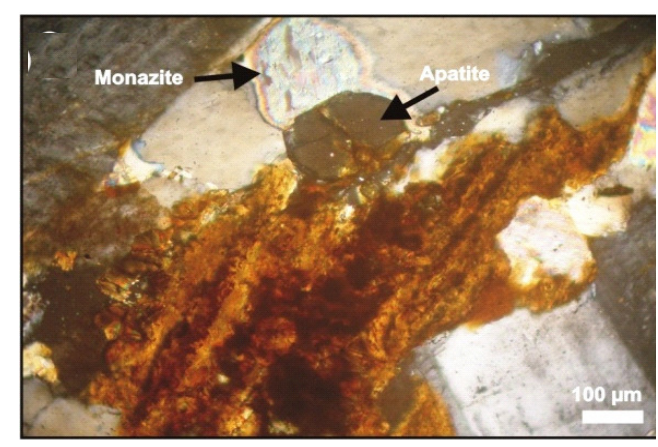

Fig.8: Photomicrograph showing large crystal of biotite associated with monazite and apatite in monzogranite, XPL 


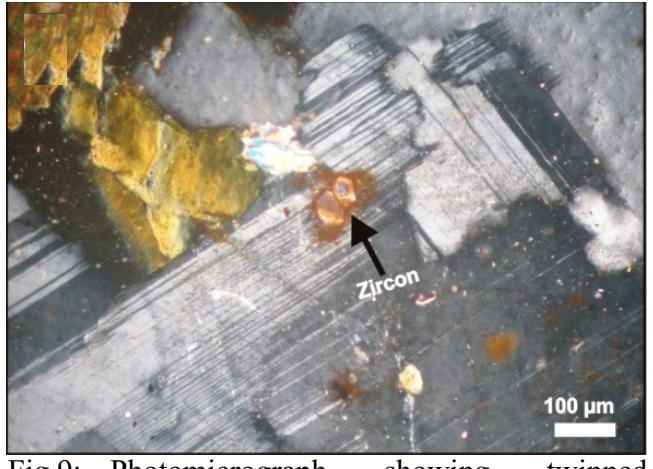

Fig.9: Photomicrograph showing twinned crystal of zircon coated by iron oxide included in plagioclase in monzogranite, XPL

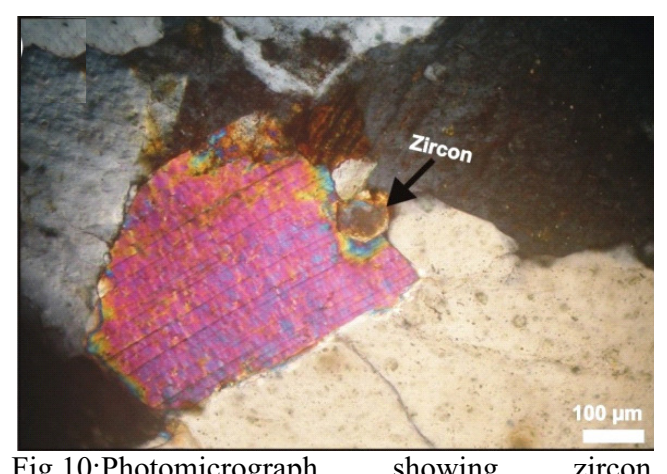

Fig.10:Photomicrograph showing zircon crystal associated with muscovite and biotite in monzogranite, XPL

usually associated with biotite and zircon.

Altered monzogranite is composed of $\mathrm{K}$ feldspar, quartz, plagioclase, biotite and rarely muscovite. Opaques (sulphides), apatite and titanite are the main accessory minerals. K-feldspar occurs as subhedral to anhedral crystals and is represented by orthoclase microperthite and microcline microperthite. It is partially altered to kaolinite and poikilitically encloses quartz and iron oxides. Quartz occurs as subhedral to anhedral crystals and interstitial grains between feldspar crystals. Quartz occurs as graphic texture in the k-feldspars (Fig. 11). Plagioclases occur as euhedral to subhedral crystals ranging from the albite to oligoclase composition $\left(\mathrm{An}_{9-14}\right)$. Plagioclase crystals exhibit simple twinning and show alteration to epidote, (Fig. 11). Biotite occurs as euhedral to subhedral elongate to flakey crystals. It is protruded in quartz and microperthitic K-feldspars. It shows alteration to chlorite. Sometimes, it may be rimed by secondary muscovite and in some cases enriched by iron oxides. Muscovite occurs in accessory amount as euhedral to subhedral colourless flakes. Apatite occurs as euhedral prismatic crystals in association with biotite and plagioclase. Titanite forms subhedral to anhedral rhombic crystals and associated with biotite. Opaques (pyrite) occur as subhedral to anhedral crystals usually associated with quartz and plagioclase (Fig. 12\&13).

\section{GEOCHEMICAL INVESTIGATIONS}

\section{Geochemistry of the Granitic Rocks}

The data of chemical analyses of the present work granodiorite, monzogranite and altered monzogranite (major oxides, trace elements and CIPW normative values) are given in Table (1). On the Ab-An-Or ternary diagram (O'Connor, 1965), the studied older granite lie in granodiorite and younger granite lie in granite field (Fig. 14). On the basis of $\mathrm{R}_{1}-\mathrm{R}_{2}$ discrimination diagram of De La-Roche

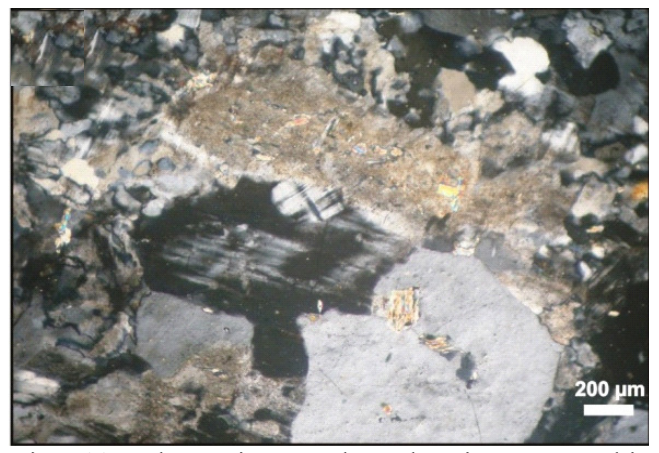

Fig. 11: Photomicrograph showing a graphic texture and plagioclase alteration to epidote in altered monzogranite, XPL 


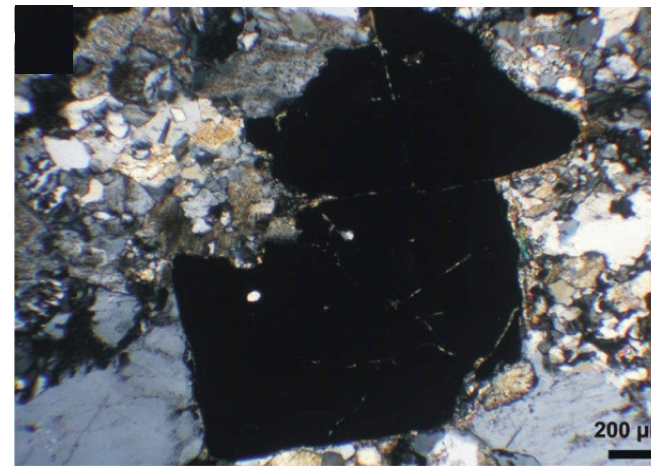

Fig.12: Photomicrograph showing pyrite crystal in altered monzogranite, XPL

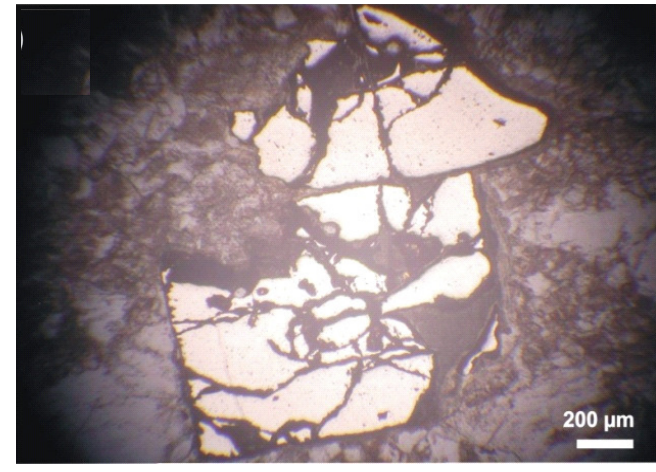

Fig.13: Photomicrograph showing pyrite crystal in altered monzogranite under ore microscope

Table 1: Major oxides (wt\%), trace elements (ppm) analyses and normative values of the studied granodiorite and monzogranite

\begin{tabular}{|c|c|c|c|c|c|c|c|c|c|c|c|c|c|c|c|}
\hline \multirow{2}{*}{ S. No. } & \multicolumn{5}{|c|}{ Granodiorite } & & & & & \multicolumn{3}{|c|}{ Monzogranite } & \multicolumn{3}{|c|}{ Altered monzogranite } \\
\hline & 1R & $2 \mathbf{R}$ & 6R & $7 \mathbf{R}$ & 9R & 1 & 2 & 3 & 4 & 5 & 6 & 7 & 8 & 9 & 10 \\
\hline $\mathrm{SiO}_{2}$ & 69.19 & 69.67 & 69.43 & 70.38 & 69.91 & 73.9 & 72.5 & 72.8 & 74.1 & 73.8 & 72.6 & 73.7 & 72.08 & 71.53 & 71.75 \\
\hline $\mathrm{TiO}_{2}$ & 0.31 & 0.37 & 0.34 & 0.32 & 0.33 & 0.04 & 0.03 & 0.06 & 0.02 & 0.03 & 0.02 & 0.01 & 0.01 & 0.02 & 0.01 \\
\hline $\mathrm{Al}_{2} \mathrm{O}_{3}$ & 15.32 & 14.57 & 14.95 & 14.37 & 14.66 & 13.4 & 13.5 & 13.5 & 13.2 & 13.2 & 12.8 & 13.2 & 12.8 & 13.1 & 12.6 \\
\hline $\mathrm{Fe}_{2} \mathrm{O}_{3}{ }^{\mathrm{t}}$ & 3.28 & 3.41 & 3.35 & 3.33 & 3.34 & 2.4 & 1.9 & 2.1 & 1.8 & 1.8 & 3.0 & 2.04 & 5.4 & 6.12 & 5.2 \\
\hline MnO & 0.07 & 0.05 & 0.06 & 0.05 & 0.06 & 0.04 & 0.06 & 0.11 & 0.03 & 0.03 & 0.09 & 0.04 & 0.06 & 0.07 & 0.06 \\
\hline MgO & 1.04 & 1.12 & 1.13 & 1.20 & 1.18 & 0.45 & 0.7 & 0.6 & 0.4 & 0.4 & 0.7 & 0.4 & 0.6 & 0.45 & 0.4 \\
\hline $\mathrm{CaO}$ & 3.38 & 3.63 & 3.26 & 3.12 & 3.20 & 0.96 & 1.3 & 1.3 & 1.45 & 0.8 & 1.2 & 0.7 & 1.2 & 1.4 & 1.3 \\
\hline $\mathrm{Na}_{2} \mathrm{O}$ & 3.43 & 3.88 & 3.66 & 3.70 & 3.68 & 4.01 & 3.88 & 3.9 & 3.68 & 3.77 & 4.38 & 4.11 & 3.12 & 3.25 & 3.8 \\
\hline $\mathrm{K}_{2} \mathrm{O}$ & 3.66 & 2.93 & 3.30 & 3.39 & 3.35 & 3.66 & 4.1 & 3.6 & 3.7 & 4.1 & 3.5 & 4.2 & 4.38 & 4.22 & 4.41 \\
\hline $\mathbf{P}_{2} \mathbf{O}_{5}$ & 0.07 & 0.15 & 0.11 & 0.09 & 0.10 & 0.03 & 0.04 & 0.03 & 0.01 & 0.04 & 0.04 & 0.05 & 0.03 & 0.03 & 0.04 \\
\hline L.O.I. & 0.54 & 0.98 & 0.76 & 0.61 & 0.66 & 0.7 & 1.5 & 1.8 & 1.1 & 1.7 & 1.3 & 1.1 & 0.7 & 0.6 & 1.00 \\
\hline Total & 100.80 & 100.87 & 100.35 & 100.48 & 100.47 & 99.19 & 99.51 & 99.8 & 99.49 & 99.67 & 99.63 & 99.55 & 100.38 & 100.79 & 100.57 \\
\hline \multicolumn{16}{|c|}{ CIPW-norm } \\
\hline $\mathbf{Q}$ & 26.94 & 27.51 & 27.35 & 28.10 & 27.67 & 34.26 & 31.06 & 33.36 & 35.43 & 34.61 & 30.90 & 32.17 & 33.84 & 32.77 & 30.02 \\
\hline Or & 21.74 & 17.39 & 19.62 & 20.08 & 19.87 & 21.90 & 24.75 & 21.73 & 22.25 & 24.76 & 21.06 & 25.25 & 26.0 & 24.92 & 26.21 \\
\hline $\mathbf{A b}$ & 29.11 & 32.91 & 31.09 & 31.31 & 31.19 & 34.28 & 33.47 & 33.64 & 31.61 & 32.54 & 37.66 & 35.30 & 26.46 & 27.42 & 32.27 \\
\hline An & 15.62 & 13.70 & 14.65 & 12.57 & 13.59 & 4.82 & 6.59 & 6.59 & 7.32 & 4.06 & 4.98 & 3.53 & 5.98 & 6.94 & 4.28 \\
\hline C & o & o & o & o & o & 1.10 & 0.31 & 0.83 & 0.50 & 1.11 & $\mathbf{0}$ & 0.62 & 0.73 & 0.62 & o \\
\hline Di(wo) & 0.31 & 1.83 & 0.67 & 1.23 & 0.98 & o & o & o & o & o & 0.45 & o & o & o & 0.92 \\
\hline Di(en) & 0.26 & 1.58 & 0.58 & 1.06 & 0.84 & o & $\mathbf{0}$ & $\mathbf{0}$ & $\mathbf{0}$ & $\mathbf{0}$ & 0.39 & $\mathbf{0}$ & o & o & 0.79 \\
\hline Hy (en) & 2.35 & 1.23 & 2.26 & 1.95 & 2.12 & 1.14 & 1.79 & 1.53 & 1.02 & 1.02 & o & 1.02 & 1.51 & 1.12 & 0.21 \\
\hline Mt & 0.23 & 0.16 & 0.20 & 0.16 & 0.20 & 0.01 & 0.11 & 0.19 & 0.04 & 0.01 & 0.24 & 0.10 & 0.17 & 0.17 & 0.17 \\
\hline $\mathrm{He}$ & 3.14 & 3.31 & 3.23 & 3.22 & 3.21 & 2.42 & 1.86 & 2.01 & 1.80 & 1.83 & 2.89 & 2.0 & 5.30 & 5.99 & 5.11 \\
\hline II & $\mathbf{0}$ & o & $\mathbf{0}$ & o & o & 0.08 & 0.06 & 0.12 & 0.04 & 0.06 & 0.04 & 0.02 & 0.02 & 0.04 & 0.02 \\
\hline \multicolumn{16}{|c|}{ Trace Elements (ppm) } \\
\hline $\mathrm{Cr}$ & 70 & 72 & 82 & 62 & 69 & 15 & 16 & 15 & 12 & 18 & 15 & 16 & 77 & 64 & 66 \\
\hline $\mathbf{N i}$ & 60 & 50 & 60 & 60 & 60 & 5 & 5 & 5 & 6 & 5 & 6 & 6 & 6 & 6 & 5 \\
\hline $\mathrm{Cu}$ & 25 & 24 & 25 & 24 & 23 & 9 & 10 & 16 & 15 & 18 & 18 & 12 & 24 & 24 & 22 \\
\hline $\mathbf{Z n}$ & 25 & 25 & 63 & 14 & 42 & 40 & 36 & 43 & 33 & 48 & 34 & 38 & 119 & 150 & 144 \\
\hline $\mathbf{Z r}$ & 67 & 81 & 53 & 49 & 85 & 300 & 223 & 212 & 321 & 166 & 265 & 245 & 54 & 54 & 53 \\
\hline $\mathbf{R b}$ & 75 & 80 & 88 & 70 & 90 & 120 & 110 & 163 & 123 & 131 & 128 & 124 & 213 & 376 & 288 \\
\hline $\mathbf{Y}$ & 22 & 26 & 19 & 16 & 29 & 44 & 41 & 61 & 37 & 36 & 39 & 50 & 19 & 18 & 20 \\
\hline $\mathbf{B a}$ & 730 & 724 & 721 & 812 & 771 & 612 & 601 & 681 & 603 & 595 & 613 & 598 & 33 & 13 & 16 \\
\hline $\mathbf{P b}$ & 10 & 25 & 20 & 15 & 25 & 22 & 27 & 28 & 30 & 30 & 28 & 27 & 543 & 1777 & 434 \\
\hline $\mathrm{Sr}$ & 420 & 435 & 410 & 414 & 443 & 122 & 74 & 107 & 62 & 137 & 120 & 156 & 39 & 6 & 6 \\
\hline $\mathbf{G a}$ & 5 & 8 & 6 & 10 & 6 & 25 & 24 & 28 & 24 & 21 & 21 & 24 & 66 & 31 & 40 \\
\hline $\mathbf{v}$ & 2 & 12 & 12 & 14 & 15 & 3 & 4 & 8 & 4 & 4 & 6 & 5 & 2 & 2 & 2 \\
\hline $\mathrm{Nb}$ & 5 & 6 & 4 & 3 & 7 & 22 & 27 & 27 & 29 & 31 & 29 & 27 & 4 & 4 & 5 \\
\hline
\end{tabular}




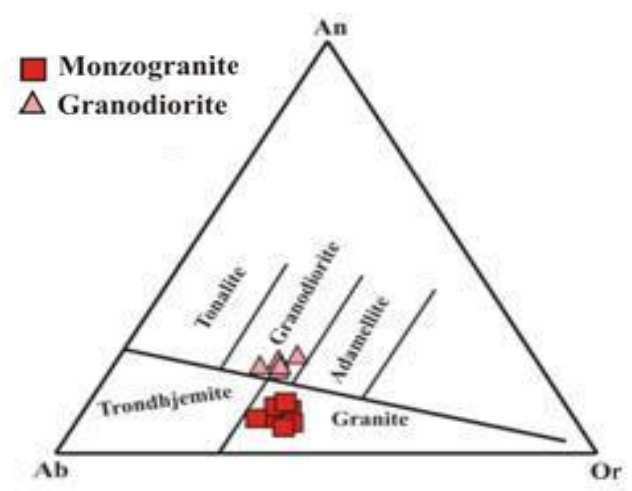

Fig.14: Ab-An-Or diagram for the studied granodiorite and monzogranite, (According to O’Connor, 1965)

et al. (1980), the studied older granite fall in the granodiorite field, whereas the younger granite in the monzogranite field (Fig. 15) except one sample lie in the syenogranite field. The studied granodiorite has metaluminous characters, while the monzogranite has peraluminous characters except one sample has metaluminous character according to the alumina saturation of Clarke (1981) on Shand's index diagram (Fig. 16). The plotting of the studied granites on the alkalinity ratio (AR) against $\mathrm{SiO}_{2}$ diagram of Wright (1969), indicate that the granodiorite has calc-alkaline and the monzogranite has alkaline nature, (Fig. 17). Chapell and White (1974) plot $\mathrm{K}_{2} \mathrm{O}$ (wt \%) versus $\mathrm{Na}_{2} \mathrm{O}$ (wt \%) for discrimination between I-type and S-type granites. Fig. (18) shows that the studied granodiorite and monzogranite lie in I-type granite. Pearce et al. (1984) discriminated between the different tectonic settings by plotting $\mathrm{Y}+\mathrm{Nb}$ versus $\mathrm{Rb}$ (Fig. 19). The figure reveals that, the studied granodiorite samples lie in volcanic arc granite field (VAG) and the monzogranite samples lie in within plate granite field (WPG).

The Ab-Qz-Or normative ternary diagram (Fig. 20) reveal that the studied granodiorite has a water-vapour pressure around $3 \mathrm{~kb}$ and temperature around $800^{\circ} \mathrm{C}$, whereas the

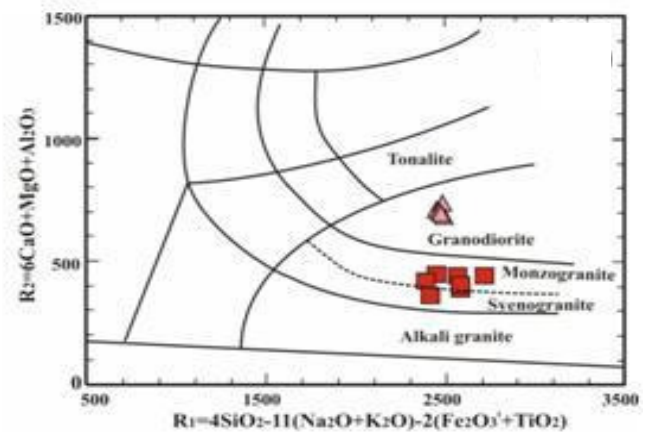

Fig.15: $\mathrm{R}_{1}-\mathrm{R}_{2}$ diagram for the studied granodiorite and monzogranite, (According to De La Roche et al., 1980), symbols as on Fig. 14

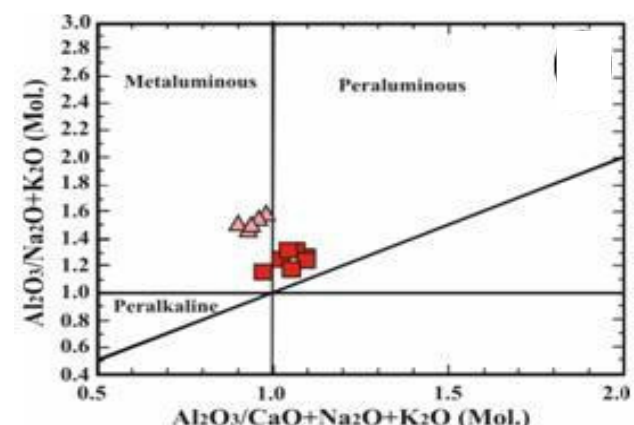

Fig.16: Shand's index diagram for the studied granodiorite and monzogranite, (According to Clarke, 1981),symbols as on Fig. 14

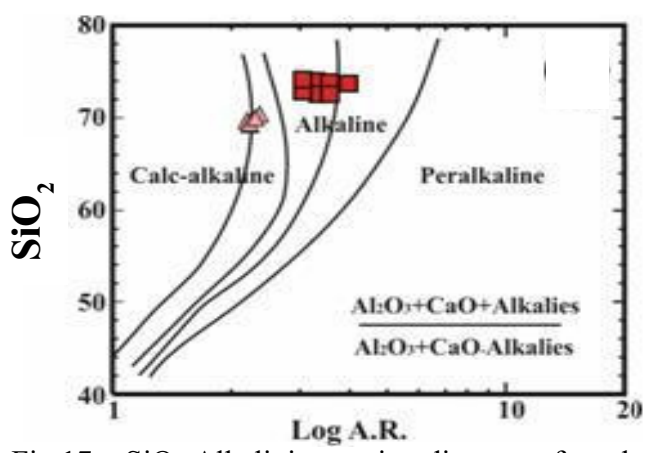

Fig.17: $\mathrm{SiO}_{2}$-Alkalinity ratio diagram for the studied granodiorite and monzogranite, (According to Wright, 1969), symbols as on Fig. 14 


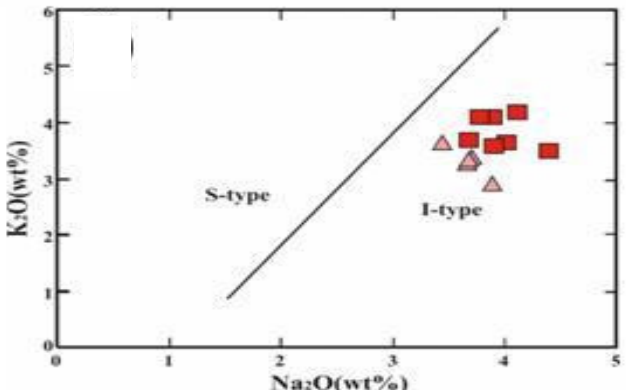

Fig. 18: $\mathrm{K}_{2} \mathrm{O}-\mathrm{Na}_{2} \mathrm{O}$ diagram for the studied granodiorite and monzogranite, (According to Chapell and White, 1974),symbols as on Fig. 14

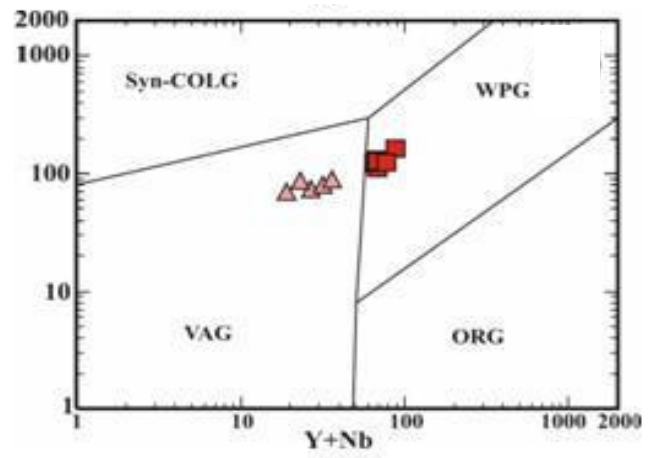

Fig.19: $\mathrm{Rb}-(\mathrm{Y}+\mathrm{Nb})$ diagram for the studied granodiorite and monzogranite, (According to Pearce et al., 1984),,symbols as on Fig. 14

monzogranite has lower water-vapour pressure $(2$ to $3 \mathrm{~kb})$ and temperature from $760^{\circ}$ to $800^{\circ}$ $\mathrm{C}$ suggesting a formation at low to moderate levels in the crust. The $\mathrm{Rb}$ versus $\mathrm{K} / \mathrm{Rb}$ diagram (Fig. 21) for the studied granodiorite and monzogranite, show that the $\mathrm{Rb}$ tend to be enriched relative to the $\mathrm{K}$ in the strongly differentiated granites and the $\mathrm{K} / \mathrm{Rb}$ ratio ranges from 304 to 405 for granodiorite and from 183.3 to 309.4 for monzogranite. The strong negative relationship between $\mathrm{K} / \mathrm{Rb}$ and $\mathrm{Rb}$ in the studied granodiorite and monzogranite suggest high degree of fractionation and origin from the same magma (Ekwere, 1985). In the $\mathrm{K} / \mathrm{Rb}$ versus $\mathrm{SiO}_{2}$ diagram,

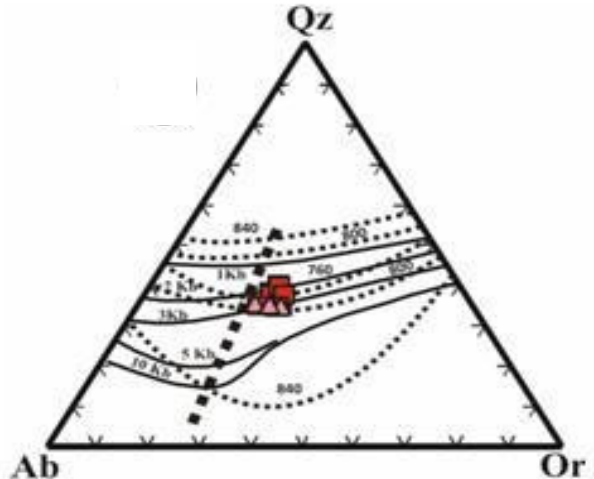

Fig.20: Ab-Qz-Or diagram for the studied granodiorite and monzogranite. The dashed lines represent the minimum melting points in the granite system at different water-vapour pressure. Pressure lines 1, $2 \& 3 \mathrm{~kb}$ After Tuttle and Bowen (1958), $5 \& 10 \mathrm{~kb}$ after Luth et al. (1964). Temperature lines after Luth et al. (1964),symbols as on Fig. 14

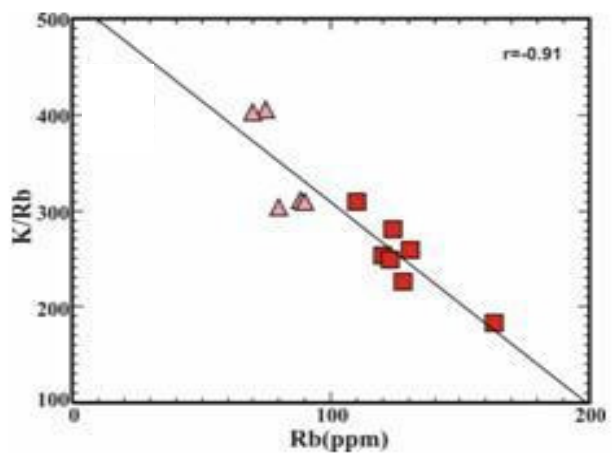

Fig.21: $\mathrm{Rb}-\mathrm{K} / \mathrm{Rb}$ diagram for the studied granodiorite and monzogranite,symbols as on Fig. 14

there is a progressive decrease in $\mathrm{K} / \mathrm{Rb}$ values with granite evolution (Fig 22). This diagram shows that the studied granodiorite was derived from moderately evolved melts and monzogranite was derived from moderately to strongly evolved melts. The ratio of $\mathrm{Ba} / \mathrm{Rb}$ decrease with magmatic differentiation due to crystallization of the feldspar (Fig. 23). In 


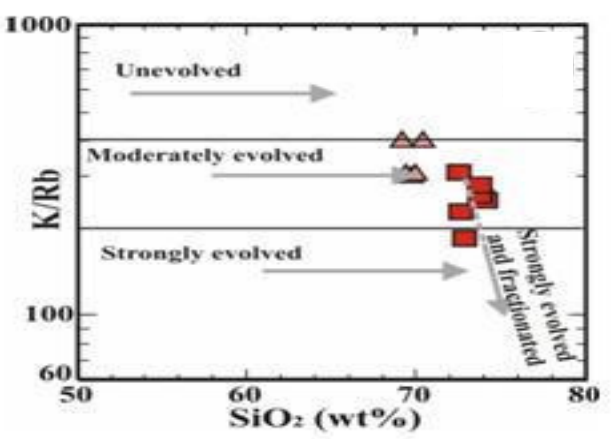

Fig.22: $\mathrm{SiO}_{2}-\mathrm{K} / \mathrm{Rb}$ diagram for the studied granodiorite and monzogranite (Fields After Blevin and chappell, 1992,symbols as on Fig. 14

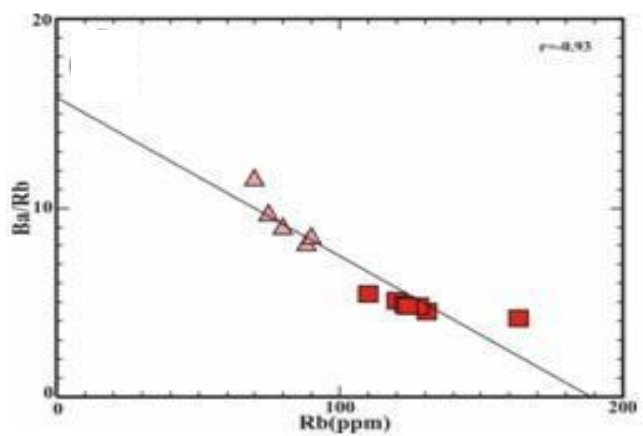

Fig.23: $\mathrm{Rb}-\mathrm{Ba} / \mathrm{Rb}$ diagram for the studied granodiorite and monzogranite,symbols as on Fig. 14

the studied granodiorite and monzogranite, the $\mathrm{Ba} / \mathrm{Rb}$ ratio ranges between 8.19 and 11.6 with an average 9.43 , and from 4.18 to 5.46 with an average 4.83 respectively, indicating the derivation from crustal origin contaminated with mantle materials (Chapman and Hall, 1997). Spider diagram of the normalized elements data of the granodiorite and monzogranite relative to chondrite of Wood et al., 1979 (Fig. 24), illustrating the enrichment of $\mathrm{Rb}, \mathrm{Ba}, \mathrm{Nb}, \mathrm{K}, \mathrm{Sr}, \mathrm{Zr}, \mathrm{Y}$ and depletion of $\mathrm{P}$, $\mathrm{Ti}, \mathrm{Mn}$ and $\mathrm{Fe}$. Spider diagram of normalized

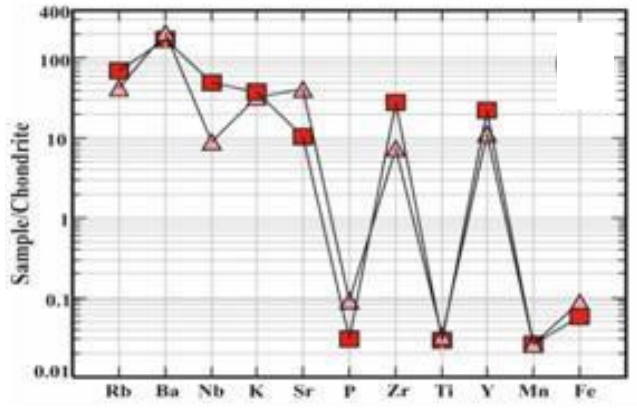

Fig.24: Spider diagram of trace elements data of the granodiorite and monzogranite normalized to Chondrite values of Wood et al., (1979),symbols as on Fig. 14

elements data of the granodiorite and monzogranite relative to average continental crust of Weaver and Tarney 1984 are given in Fig. 25. They show the values of $\mathrm{Rb}, \mathrm{Ba}, \mathrm{K}, \mathrm{Nb}$, $\mathrm{Sr}, \mathrm{Zr}$, and $\mathrm{Y}$ are distributed around the unity, and depletion of $\mathrm{P}$ and Ti.

\section{Geochemistry of Altered Monzogranite}

The studied monzogranite suffered from the alteration processes that appear in the increasing in $\mathrm{Fe}_{2} \mathrm{O}_{3}{ }^{\mathrm{t}}, \mathrm{MnO}, \mathrm{CaO}, \mathrm{K}_{2} \mathrm{O}, \mathrm{Rb}$, $\mathrm{Pb}, \mathrm{Cr}, \mathrm{Ni}, \mathrm{Zn}, \mathrm{Cu}, \mathrm{Ga}$ and the depletion in $\mathrm{SiO}_{2}, \mathrm{TiO}_{2}, \mathrm{Al}_{2} \mathrm{O}_{3}, \mathrm{MgO}, \mathrm{Na}_{2} \mathrm{O}, \mathrm{P}_{2} \mathrm{O}_{5}, \mathrm{Ba}$, $\mathrm{Nb}, \mathrm{Sr}, \mathrm{Zr}$, Y and $\mathrm{V}$ (Fig. 26\&27). Plotting their samples on the $\mathrm{Na} \%-\mathrm{K} \%$ diagram after Cuney et al., 1989 (Fig. 28) shows that the altered samples lie near the K-metasomatism trend. The altered monzogranite samples are plotted on the AKF ternary diagram (Fig. 29) (after Meyer and Hemley, 1967), where $\mathrm{A}=\mathrm{Al}_{2} \mathrm{O}_{3}-\left(\mathrm{Na}_{2} \mathrm{O}+\mathrm{K}_{2} \mathrm{O}\right), \mathrm{K}=\mathrm{K}_{2} \mathrm{O}$ and $\mathrm{F}=\mathrm{FeO}+\mathrm{MnO}+\mathrm{MgO}$, where the samples fall in the propylitic facies.

The most prominent geochemical characteristics of these altered samples declare substantial variations in the concentrations of $\mathrm{Na}, \mathrm{Ca}, \mathrm{Mg}$ and $\mathrm{Fe}$ (Fig. 30) (Le Maitre et al., 1989). Increasing alteration intensity is coupled with a gradual decrease in $\mathrm{Na}_{2} \mathrm{O}$ and 


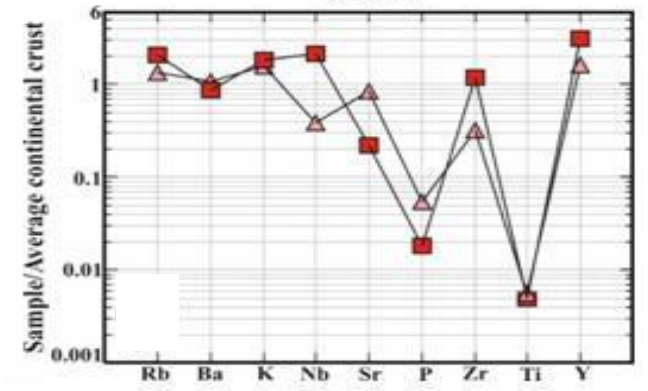

Fig.25: Spider diagram of trace elements data of the granodiorite and monzogranite normalized to average continental crust values of Weaver and Tarney (1984),(Symbols as on Fig.14)

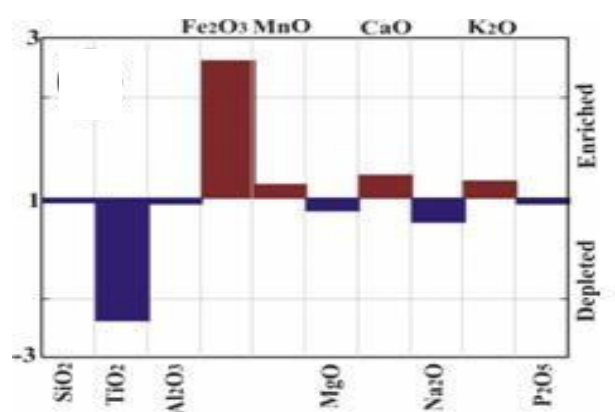

Fig.26: Enrichment-depletion diagram of the average major oxides ( $\mathrm{wt} \%$ ) of the studied altered monzogranite compared with the average composition of the fresh one

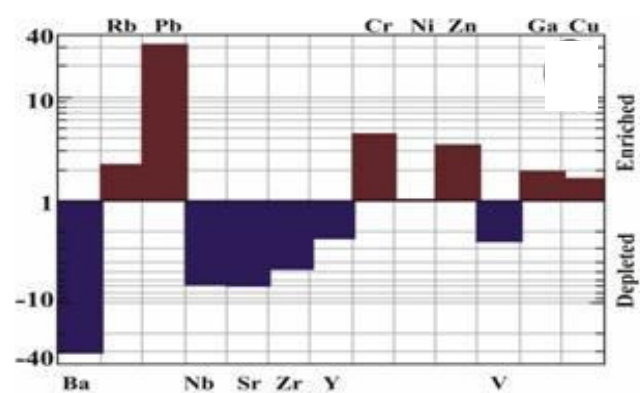

Fig.27: Enrichment-depletion diagram of the average trace elements (ppm) of the studied altered monzogranite compared with the average composition of the fresh one

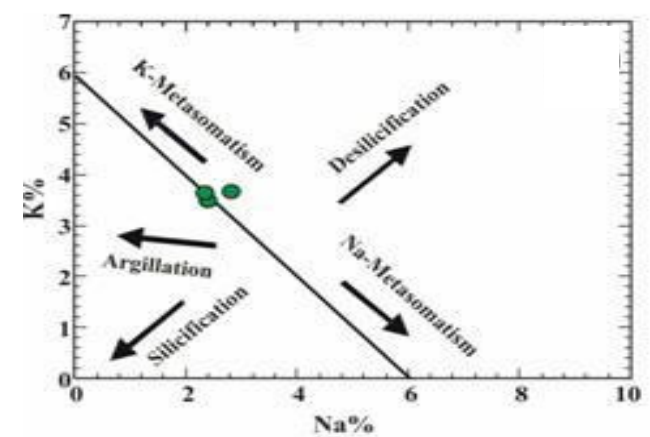

Fig.28: Na-K diagram of the altered monzogranite, (According to Cuney et al., 1989)

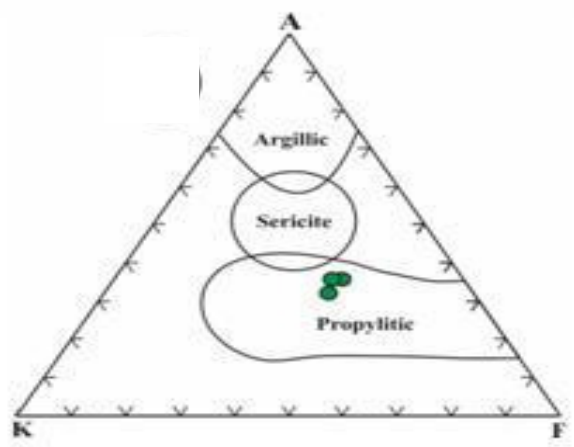

Fig.29: A-K-F diagram of altered monzogranite, (According to Meyer and Hemley, 1967)

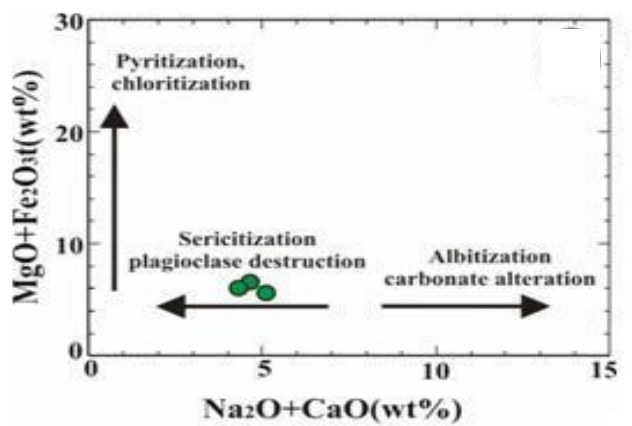

Fig. 30: $\left(\mathrm{Na}_{2} \mathrm{O}+\mathrm{CaO}\right)-\left(\mathrm{MgO}+\mathrm{Fe}_{2} \mathrm{O}_{3}{ }^{\mathrm{t}}\right)$ diagram of the studied altered monzogranite, (According to Le Maitre et al., 1989) 
$\mathrm{CaO}$, culminating in the intensely altered samples having low $\mathrm{Na}_{2} \mathrm{O}+\mathrm{CaO}$ values $\mathrm{wt} \%$. The altered monzogranite samples lie in plagioclase destruction and formation of muscovite/ sericitization trend.

A number of alteration indices and element ratios were tested on the altered monzogranite data set. This index (Ishikawa alteration index: $\left[100 \quad\left(\mathrm{MgO}+\mathrm{K}_{2} \mathrm{O}\right) /\right.$ $\left.\left(\mathrm{MgO}+\mathrm{K}_{2} \mathrm{O}+\mathrm{CaO}+\mathrm{Na}_{2} \mathrm{O}\right)\right]$ relates to the replacement of plagioclase by sericite and chlorite during hydrothermal alteration (Ishikawa et al., 1976; large et al., 2001). The index is superior to using $\mathrm{Na}_{2} \mathrm{O}$ alone because of its ability to distinguish alkali depletion related to hydrothermal alteration. Alteration box plot is used to characterize the different alteration trends and regional diagenetic alteration. The altered samples plot in the K-feldspar-albite trend (Fig. 31).

\section{RADIOMETRIC INVESTIGATIONS}

Uranium mobilization (eUm) in the studied rock types can be calculated as follows; the uranium mobilization is calculated as the difference between the measured eU and the expected original uranium, which calculated by dividing the measured eTh by the average $\mathrm{eTh} / \mathrm{eU}$ ratio in the crustal acidic rocks (original uranium $=\mathrm{eTh} / 3.5$ according to Clark et al., 1966) to give the leaching values of uranium (eUm=eU-eTh/3.5). Positive values indicate uranium addition by mobilization, whereas negative values indicate migration of the uranium by leaching.

The eU contents in the studied granodiorite range from 2 to $7 \mathrm{ppm}$ with an average $4.6 \mathrm{ppm}$. The eTh contents range from 13 to $18 \mathrm{ppm}$ with an average $15.40 \mathrm{ppm}$, while the average of $(\mathrm{eTh} / \mathrm{eU})$ ratios are $4.07 \mathrm{ppm}$ and average of eUm is 0.2 (Table 2 \& Fig. 32) indicating magmatic origin. The eU contents in the monzogranite vary from 5 to 9 ppm with an average of $7.43 \mathrm{ppm}$. The eTh contents range from 14 to $25 \mathrm{ppm}$ with an average of 19.14 $\mathrm{ppm}$, while the average of $(\mathrm{eTh} / \mathrm{eU})$ ratios is 2.67 and average of $\mathrm{eU}$ is 1.96 indicating

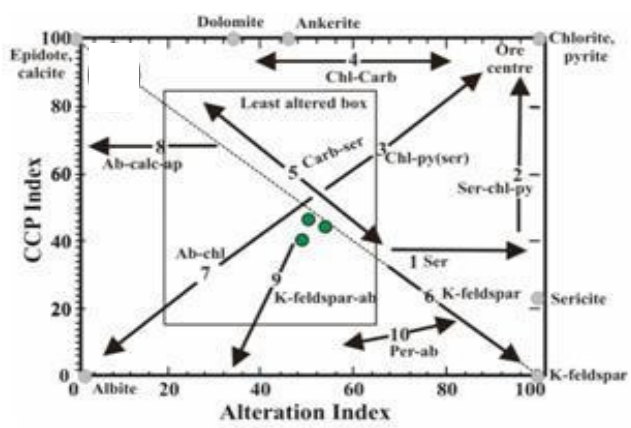

Fig.31: A hydrothermal and diagenetic alteration box plots for the studied altered monzogranite (Large et al., 2001). Trend No. 9 After Gifkins and Allen, (2001)

the addition of uranium from the surrounding rocks (Table $2 \&$ Fig. 32). The eU contents in the studied altered monzogranite vary from 15 to $20 \mathrm{ppm}$ with an average of $17.33 \mathrm{ppm}$. The eTh contents range from 24 to $30 \mathrm{ppm}$ with an average of $27 \mathrm{ppm}$, while the average of $(\mathrm{eTh} / \mathrm{eU})$ ratios is 1.57 and average of $\mathrm{eU}$ is 9.62 indicating addition of uranium from the surrounding rocks (Table 2 \& Fig. 32).

The binary relations of eU with eTh and eTh/eU may provide an indicator of the geochemical behavior of $\mathrm{U}$ and $\mathrm{Th}$ in the studied rock samples. The plot of eU versus eTh illustrates that there are a strong positive relations $(r=0.78)$ referring to their magmatic origin (Fig. 33). The eTh/eU ratio in fresh and altered monzogranite is less than 3 in all samples except one sample (Fig. 34) indicating the enrichment of uranium rather than thorium and there is a negative correlation between $\mathrm{eU}$ and $\mathrm{eTh} / \mathrm{eU}(\mathrm{r}=-0.72)$.

There is a positive relation between eU and alkali oxides $\left(\mathrm{Na}_{2} \mathrm{O}+\mathrm{K}_{2} \mathrm{O}\right)$, indicating the incompatible behavior of the uranium during magmatic differentiation (Fig. 35). The relationship between eU and $\mathrm{Zr}$ (Fig. 36) show negative correlation $(r=-0.79)$ from fresh to altered monzogranite. The plotting of eU verses $\mathrm{Pb}$ shows positive relation and enrich- 
GEOLOGY, GEOCHEMISTRY AND RADIOACTIVITY OF THE

Table 2: Radiometric measurements in the granodiorite, monzogranite and altered monzogranite

\begin{tabular}{|c|c|c|c|c|c|c|c|c|c|}
\hline S. No. & Rock Type & $\begin{array}{r}\mathbf{e U} \\
(\mathbf{p p m})\end{array}$ & $\begin{array}{r}\mathbf{e T h} \\
(\mathbf{p p m})\end{array}$ & $\begin{array}{r}\mathbf{R a} \\
(\mathbf{p p m})\end{array}$ & $\mathbf{K} \%$ & $\mathbf{e T h} / \mathbf{e U}$ & eU/eTh & eUm & $\begin{array}{r}\mathbf{P}= \\
\text { eU/Ra }\end{array}$ \\
\hline 1R & \multirow{6}{*}{ Granodiorite } & 2 & 15 & 2 & 2.82 & 7.50 & 0.13 & -2.29 & 1.0 \\
\hline $2 \mathbf{R}$ & & 5 & 18 & 3 & 2.90 & 3.60 & 0.27 & -0.14 & 1.67 \\
\hline GR & & 6 & 13 & 2 & 1.64 & 2.16 & 0.46 & 2.29 & 3.0 \\
\hline $7 R$ & & 7 & 17 & 2 & 2.43 & 2.43 & 0.41 & 2.14 & 3.50 \\
\hline 9R & & 3 & 14 & 2 & 1.84 & 4.67 & 0.21 & -1.0 & 1.50 \\
\hline Average & & 4.60 & 15.40 & 2.20 & 2.33 & 4.07 & o.30 & 0.20 & 2.13 \\
\hline $\mathbf{1}$ & \multirow{8}{*}{ Monzogranite } & 9 & 19 & 7 & 2.88 & 2.11 & 0.47 & 3.57 & 1.29 \\
\hline 2 & & 8 & 16 & 7 & 3.08 & 2 & 0.50 & 3.43 & 1.14 \\
\hline 3 & & 6 & 14 & 6 & 3.81 & 2.33 & 0.43 & 2.0 & 1.0 \\
\hline 4 & & 7 & 17 & 8 & 3.55 & 2.43 & 0.41 & 2.14 & 0.88 \\
\hline 5 & & 5 & 22 & 4 & 3.99 & 4.40 & 0.23 & -1.29 & 1.25 \\
\hline 6 & & 9 & 25 & 5 & 3.10 & 2.78 & 0.36 & 1.86 & 1.80 \\
\hline 7 & & 8 & 21 & 4 & 2.88 & 2.63 & 0.38 & 2.0 & 2.0 \\
\hline Average & & 7.43 & 19.14 & 5.86 & 3.33 & 2.67 & 0.40 & 1.96 & 1.34 \\
\hline 8 & \multirow{3}{*}{$\begin{array}{r}\text { Altered } \\
\text { monzogranite }\end{array}$} & 15 & 27 & 7 & 4.29 & 1.8 & 0.56 & 7.29 & 2.14 \\
\hline 9 & & 17 & 24 & 4 & 3.99 & 1.41 & 0.71 & 10.14 & 4.25 \\
\hline 10 & & 20 & 30 & 4 & 3.43 & 1.50 & 0.67 & 11.43 & 5 \\
\hline Average & & 17.33 & 27 & 5 & 3.90 & 1.57 & 0.64 & 9.62 & 3.7 \\
\hline
\end{tabular}

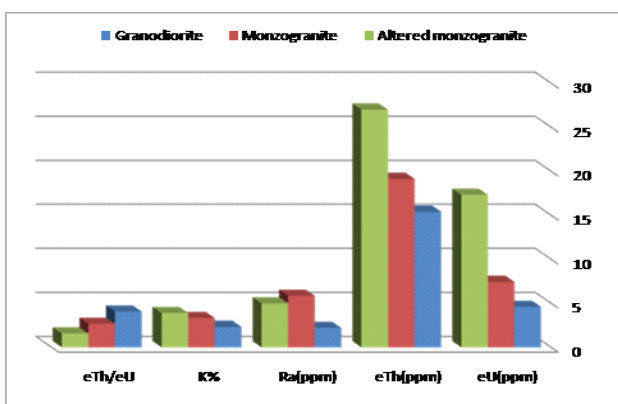

Fig.32: Radiometric measurements in the studied granodiorite, monzogranite and altered monzogranite

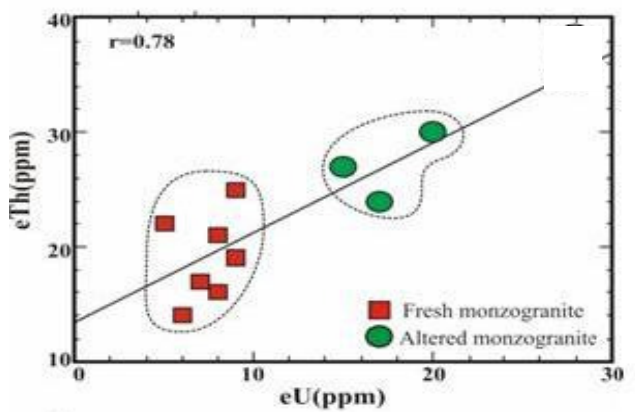

Fig.33: eU-e'lh diagram for the studied tresh and altered monzogranites

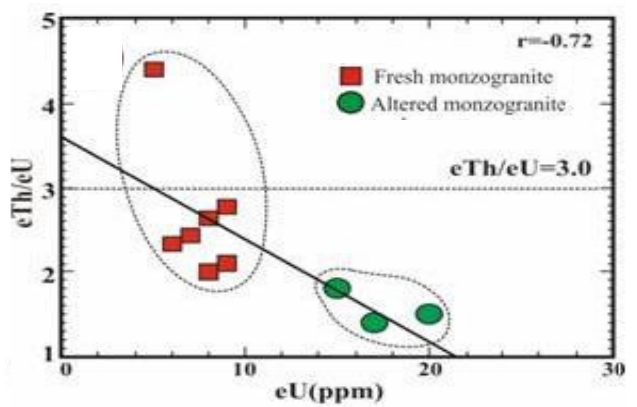

Fig.34: eU-(eTh/eU) diagram for the studied fresh and altered monzogranites

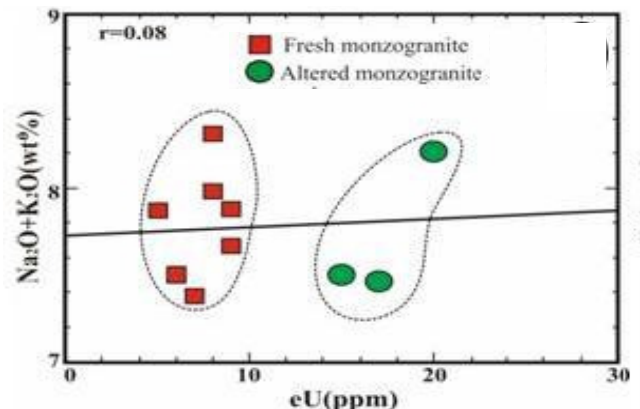

Fig.35: eU- $\left(\mathrm{Na}_{2} \mathrm{O}+\mathrm{K}_{2} \mathrm{O}\right)$ diagram for the studied fresh and altered monzogranites 


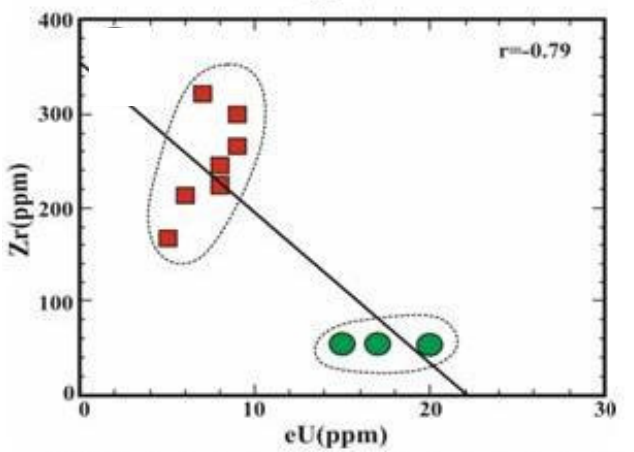

Fig.36: eU-Zr diagram for the studied fresh and altered monzogranites

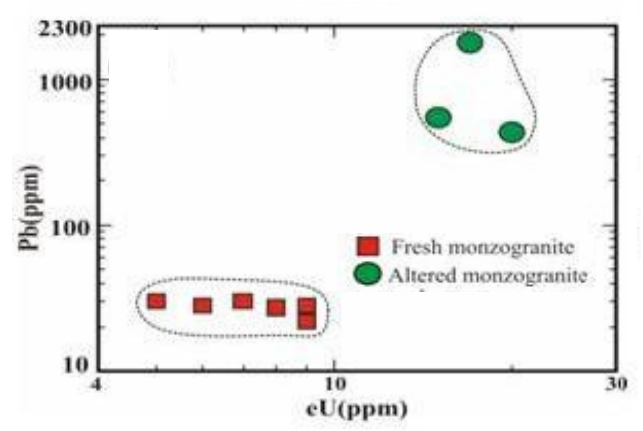

Fig.37: eU-Pb diagram for the studied fresh and altered monzogranites

ment from fresh to altered monzogranite (Fig. 37). On the eU verses $\mathrm{Nb}$ variation diagram (Fig. 38) show strong negative relation $(r=-0.95)$ from fresh to altered monzogranite.

\section{Disequilibrium Factor}

In a closed system, the process of radioactive decay of $U$ and $T h$ reaches a state of equilibrium when the production rate of any intermediate daughter in the decay chain is equal to its parent decay rate. In a case of $U^{238}$ series, the equilibrium state is attained in approximately $1.5 \times 106$ years, while 40 years are sufficient for $\mathrm{Th}^{232}$ series (Faure, 1986). Under surface and near surface geological conditions, a closed system may not be attained. This is

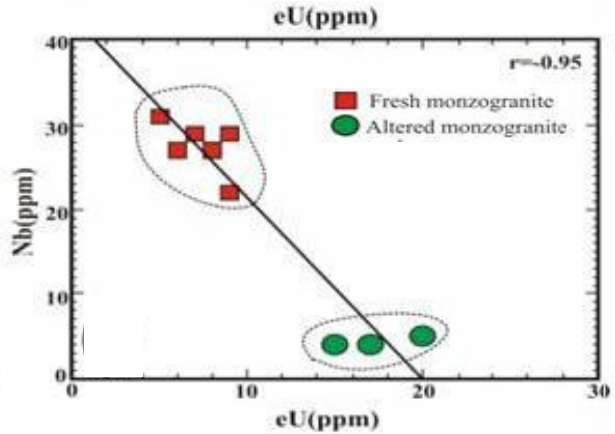

Fig.38: eU-Nb diagram for the studied fresh and altered monzogranites

due to the weathering and circulation of fluids through channels which remove some of the daughter elements particularly radon. In addition, these conditions may add or remove uranium and hence disequilibrium arises.

The radioactive equilibrium of the studied granodiorite, monzogranite and altered monzogranite can be determined by calculation as follows; P factor $=\mathrm{eU} / \mathrm{Ra}$ (El-Galy, 1998; Surour et al., 2001; Raslan and El-Feky, 2012; Nadaa and Aly, 2014). The average P factor values are 2.13, 1.34 and 3.70 for granodiorite, monzogranite and altered monzogranite respectively. This values more than one, indicating disequilibrium (Table 2).

\section{MINERALOGICAL FEATURES OF ALTERED MONZOGRANITE}

The identified heavy minerals in the studied altered monzogranite rock are pyrite, sphalerite, galena, monazite, hematite and goethite.

\section{Pyrite $\left(\mathrm{FeS}_{2}\right)$}

It is found as euhedral crystals of cubic habit (Fig. 39). The pyrite is characterized by its pale brass yellow colour, while the colour varies from deep red to black in case of alteration. Pyrite is easily altered to hematite and/or goethite. Pyrite is confirmed by X-ray diffraction (XRD) (Figs. 40-41\&45). 


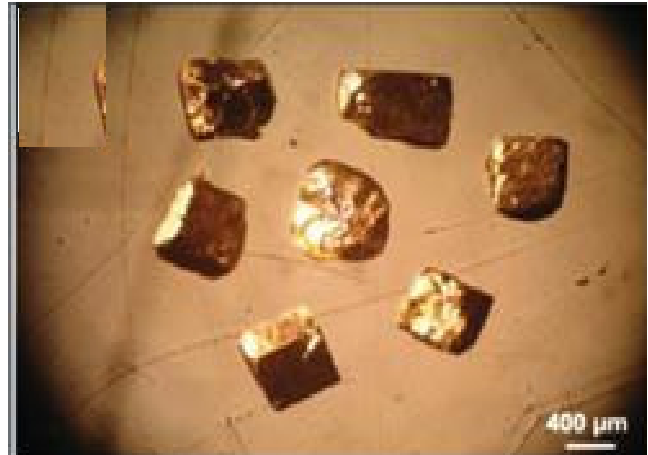

Fig. 39: Pyrite grains from altered monzogranite

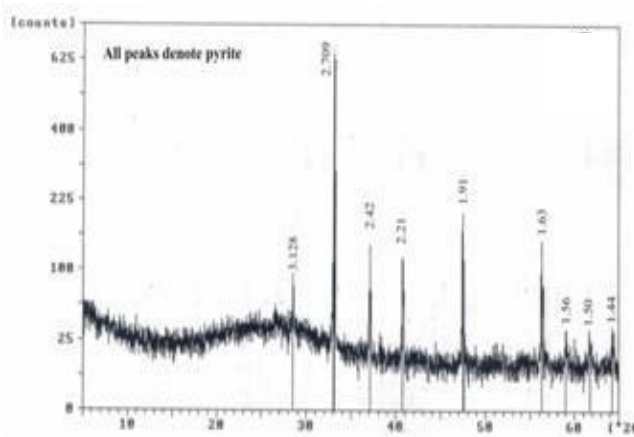

Fig.40: X-ray diffractogram of pyrite from altered monzogranite

\section{Sphalerite $[(\mathbf{Z n}, \mathbf{F e}) \mathrm{S}]$}

It is the most important zinc sulphide minerals. It is commonly associated with other sulphide minerals, such as galena and pyrite. It is confirmed by XRD technique (Fig. 41).

\section{Galena (PbS)}

Galena has a cubic structure and often a cubic or cube-octahedral morphology and a perfect cubic cleavage (Fig. 42). Its colour is lead-grey, and its luster varies from metallic to faded metallic. The mineral is a major lead ore but silver, bismuth and thallium are also extracted from galena. Galena is confirmed by XRD technique (Fig. 43).

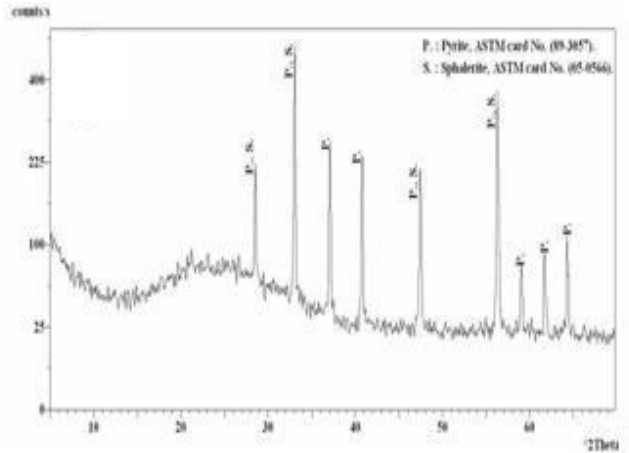

Fig.41: X-ray diffractogram of pyrite and sphalerite from altered monzogranite

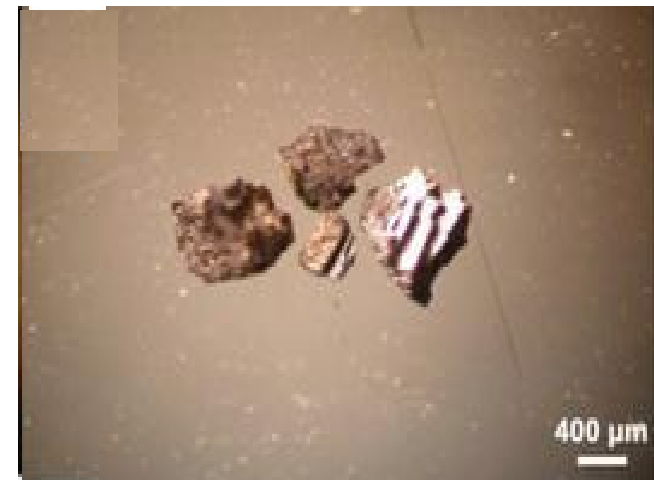

Fig.42: Galena grains from altered monzogranite,

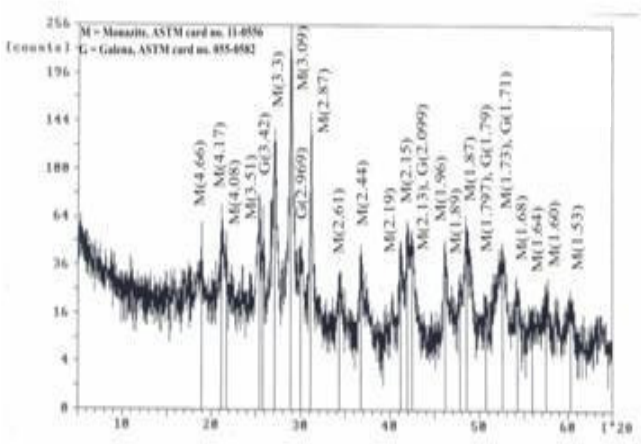

Fig.43: X-ray diffractogram of Monazite and galena from altered monzogranite 


\section{Monazite [(Ce, La, Nd, Sm, Th) $\left.\mathbf{P O}_{4}\right]$}

Monazite have a wide range of LREE and is iso-structural with cheralite (RE,Th, $\mathrm{Ca}, \mathrm{U})(\mathrm{P}, \mathrm{Si}) \mathrm{O}_{4}$ and with huttonite $\left(\mathrm{ThSiO}_{4}\right)$, both of which have highly ceric REE distributions (Bowles et al., 1980; Pabst and Hutton, 1951). Thorium is usually exists in monazite in substitution for the REE. Jensen (1967) concluded that the monazite structure would accept REE ions with ionic radii between those of $\mathrm{La}$ and $\mathrm{Eu}$. It is confirmed by XRD technique (Fig. 43).

\section{Hematite $\left(\mathrm{Fe}_{2} \mathrm{O}_{3}\right)$}

It exists as granular grains with reddish brown to black in colour (Fig. 44). The mineral is hexagonal system and not susceptible to magnetization. It is confirmed by XRD technique (Fig. 45).

\section{Goethite [FeO (OH)]}

It is reddish and brownish black in colour (Fig. 46) and formed due to the disintegration of pyrite $\left(\mathrm{FeS}_{2}\right)$. It is confirmed by XRD technique (Fig. 45).

\section{Microprobe Studies}

Pyrite is one of the most useful indicators of the environment of ore deposition because of its refractory nature, wide distribution in natural environments. Two pyrite grains

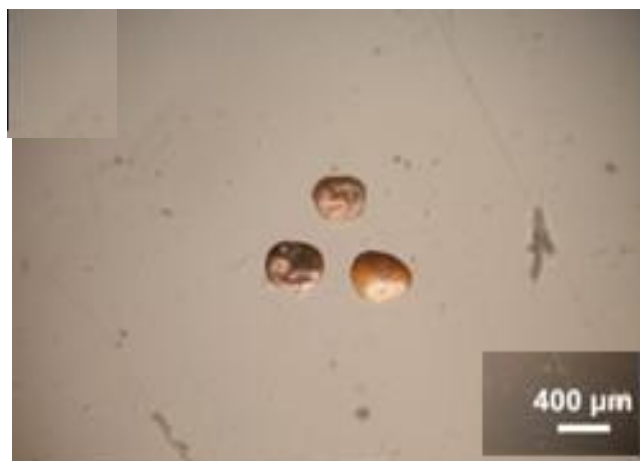

Fig.44: Hematite grains from altered monzogranite

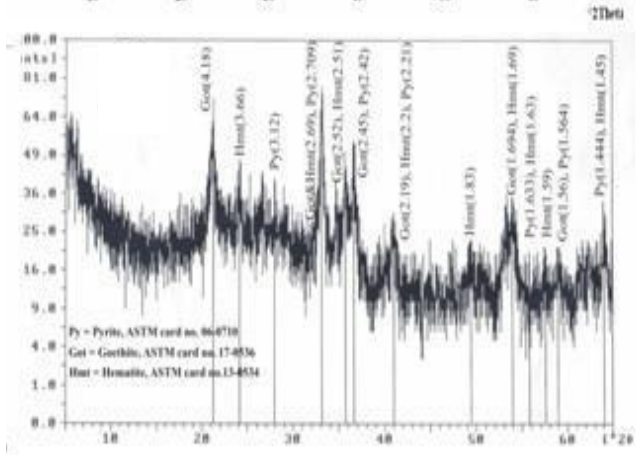

Fig.45: X-ray diffractogram of Pyrite, hematite and goethite from altered monzogranite

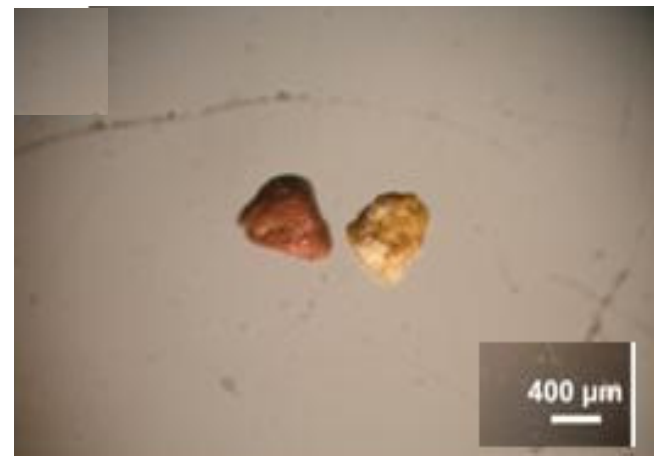

Fig.46: Goethite grains from altered monzogranite

were systematically selected for electron microprobe to study the chemistry and elemental replacement in their lattice structure. Detected minor elements in pyrite are Co $(0.048 \mathrm{wt} \%)$, Se $\left(0.0115 \mathrm{wt}^{\mathrm{O}} \%\right)$, Mn $(0.0022 \mathrm{wt} \%)$, and $\mathrm{Cu}$ $(0.0008 \mathrm{wt} \%)$. Ag content is $0.0009 \mathrm{wt} \%$ in position number 1 only and $0 \mathrm{wt} \%$ in all the other positions and each of $\mathrm{Ni}, \mathrm{Zn}, \mathrm{Cd}, \mathrm{In}$, $\mathrm{Sb}, \mathrm{Pb}$ and $\mathrm{Bi}$ have zero values $(0 \mathrm{wt} \%)$ in all positions (Fig. 47 and Table 3). Inclusions in pyrite can be understood as a tracer of genesis and type of granite environment. The hydrothermal pyrite origin indicates presence of sulphosalt and sulphide inclusions such as sphalerite and galena. 

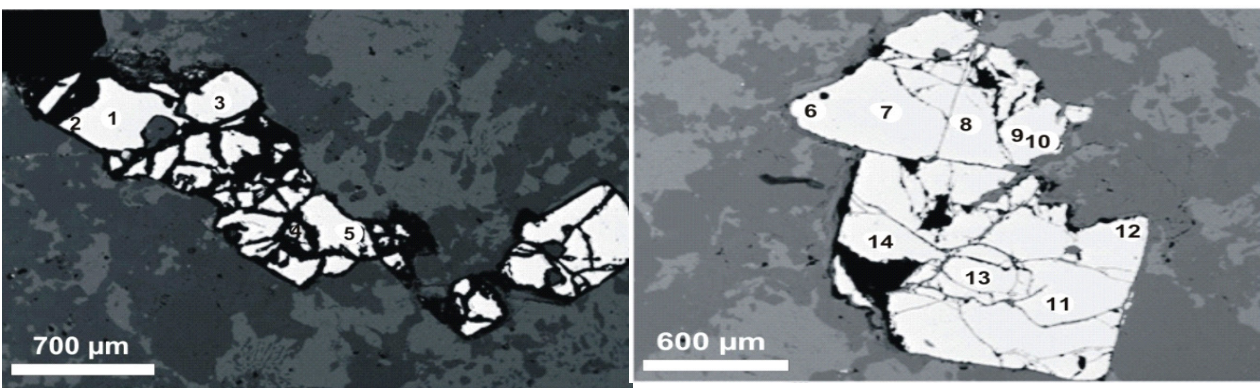

Fig. 47: Back-scattered- electron images of pyrite grains

Table 3: Microprobe analyses of element composition (wt $\%$ ) of pyrite mineral

\begin{tabular}{|c|c|c|c|c|c|c|c|c|}
\hline Spot No. & $\mathbf{S}$ & $\mathbf{F e}$ & Co & Se & Mn & $\mathrm{Cu}$ & Ag & Total \\
\hline 1 & 53.26 & 46.12 & 0.0419 & 0.0121 & 0.0034 & 0 & 0.0009 & 99.44 \\
\hline 2 & 53.52 & 45.77 & 0.0441 & 0.0228 & 0.0045 & 0 & 0 & 99.36 \\
\hline 3 & 53.45 & 46.21 & 0.0482 & 0.0081 & 0 & 0 & o & 99.72 \\
\hline 4 & 53.24 & 45.89 & 0.0502 & 0.01 & 0 & 0.0017 & 0 & 99.19 \\
\hline 5 & 53.32 & 45.93 & 0.0494 & 0.0201 & 0.001 & 0.0007 & 0 & 99.32 \\
\hline 6 & 53.46 & 45.9 & 0.0438 & 0.0069 & 0.0056 & 0.0039 & $\mathbf{0}$ & 99.42 \\
\hline 7 & 53.2 & 46.05 & 0.0513 & 0.0205 & 0.0025 & 0 & 0 & 99.32 \\
\hline 8 & 53.52 & 46.34 & 0.0424 & 0.0222 & 0 & 0 & 0 & 99.93 \\
\hline 9 & 53.61 & 46.14 & 0.053 & 0.0158 & 0.0001 & 0.0017 & 0 & 99.82 \\
\hline 10 & 53.18 & 46.37 & 0.0505 & 0.0144 & 0.0008 & 0.0009 & 0 & 99.61 \\
\hline 11 & 53.2 & 46.97 & 0.0503 & 0 & 0.0048 & 0.0002 & $\mathbf{0}$ & 100.23 \\
\hline 12 & 53.63 & 46.63 & 0.0489 & 0.0029 & 0.0031 & 0 & $\mathbf{0}$ & 100.32 \\
\hline 13 & 54.16 & 46.57 & 0.0482 & 0.0058 & 0.001 & 0.0019 & $\mathbf{0}$ & 100.79 \\
\hline 14 & 53.92 & 46.64 & 0.0514 & 0 & 0.0041 & 0 & 0 & 100.62 \\
\hline Average & 53.48 & 46.25 & 0.048 & 0.0115 & 0.0022 & 0.0008 & 0.000064 & 99.79 \\
\hline
\end{tabular}

\section{SUMMARY AND CONCLUSIONS}

The basement rocks exposed in the area include ophiolitic mélange, metabasalt, quartz-diorite, granodiorite, monzogranite. The monzogranite suffered in some parts from alteration processes and enriched in sulphide minerals.

Petrographically, the studied monzogranite is composed of $\mathrm{K}$-feldspar, quartz, plagioclase $\left(\mathrm{An}_{8-15}\right)$, biotite and minor amounts of muscovite. Zircon, apatite, monazite and opaques are accessories. Altered monzogranite is composed of $\mathrm{K}$-feldspar, quartz, plagioclase, biotite and rarely muscovite. Opaques (sulphides), apatite and titanite are accessories.

Geochemically, the granodiorite has metaluminous character, calc-alkaline affinity, emplaced in volcanic arc setting and crystallized under moderate water-vapour pressure around $3 \mathrm{~Kb}$ and temperature around $800^{\circ} \mathrm{C}$. The studied monzogranite has peraluminous character, alkaline affinity, emplaced in within plate setting and crystallized under low water- vapour pressure $(2-3 \mathrm{~Kb})$ and temperature $\left(760-800^{\circ} \mathrm{C}\right)$. The propylitic and K-metasomatism are the main alteration types in the studied altered monzogranites, while plagioclase destructed and formed epidote. There is increase in $\mathrm{Fe}$ due to the presence of pyrite, hematite and goethite minerals, while the increase in $\mathrm{Pb}$ and $\mathrm{Zn}$ due to the presence of galena and sphalerite respectively.

Radiometrically, the radioactivity increases towards the more acidic rocks, from granodiorite to altered monzogranite. The average $\mathrm{eU}$ content in the fresh monzogranite is less 
than twice Clark value (4 ppm); this indicates the monzogranite is not uraniferous. The altered monzogranite had eU more than twice Clark value; this indicates the altered monzogranite was uraniferous. So, the study monzogranite has been subjected to post-magmatic changes.

Mineralogically, the identified heavy minerals are pyrite, sphalerite, galena, monazite, hematite and goethite.

From microprobe studies, pyrite was rich in $\mathrm{Co}(0.048 \mathrm{wt} \%)$, Se $(0.0115 \mathrm{wt} \%)$ and poor in $\mathrm{Mn}(0.0022 \mathrm{wt} \%)$ and $\mathrm{Cu}(0.0008 \mathrm{wt} \%)$. Cobalt and Selenium concentrated in pyrite as solid solution substituting for iron.

\section{REFERENCES}

Akaad, M.K., and Noweir, A.M., 1980. Geology and lithostratigraphy of the Arabian Desert Orogenic Belt of Egypt between latitudes $25^{\circ}$ $35^{\prime}$ and $26^{\circ} 30^{\prime} \mathrm{N}$. In evolution and mineralization of the Arabian-Nubian Shield, 4, 127-136.

Ali, M.A., and Lentz, D.R., 2011. Mineralogy, geochemistry and age dating of shear zone-hosted Nb-Ta-, Zr-Hf-, Th-, U-bearing granitic rocks in the Ghadir and El-Sella areas, South Eastern Desert, Egypt. Chin. J. Geochem., 30, 453-478. DOI: 10.1007/s11631-011-0531-5.

Basta, F.F., 1983. Geology and geochemistry of the ophiolitic mélange and other rock units in the area around and west of Gabal Ghadir, Eastern Desert, Egypt. Ph.D. Thesis, Cairo Univ., $137 \mathrm{p}$.

Blevin, P.L., and chappell, B.W., 1992. The role of magma sources, oxidation states and fractionation in determining the granite metallogeny of eastern Australia: Trans. Roy. Soc. Edinburgh. Earth Sci., 83, 305-316.

Bowles, J.F.W.; Jobbins, E.A., and Young, B.R., 1980. A re-examination of cheralite. Mineral. Mag., 43, 885-888.

Chapman, C.A., and Hall, A., 1997. The nature and origin of granite. Boundary row, London. $387 \mathrm{p}$.
Chappell, B.W., and White, A.J.R., 1974. Two contrasting granite types. Pacific Geol., 8, 173174.

Clarke, M.B., 1981. The mineralogy of peraluminous granites: a review. Can. Contrib. Miner. Petrol., 79, 3-17.

Clarke, S.P.J.R.; Peterman, Z.E., and Heier, K.S.. 1966. Abundances in uranium, thorium and potassium. In :Handbook of physical constants. Geol. Soc. Amer., Memoir, 97, 521-541.

Cuney, M.; Leroy, J.; Volivezo, A.; Daziano, C.; Gambda, B.; Zarco, A.J.; Morello, D.; Ninci, C., and Molina, P., 1989. Metallogenesis of the uranium mineralized Achala granitic complex, Argentina: comparison with Hercynian peraluminous leucogranites of West Europe. Proc. Tech. Comm. Meetings, Vienna, TECDOC453, I. A. E. A. Vienna, 211-232.

De La Roche, H.; Leterrier, J.; Grandelaude, P., and Marchal, M., 1980. A classification of volcanic and plutonic rocks using $\mathrm{R}_{1}-\mathrm{R}_{2}$ diagram and major element analyses. Its relationships with current nomenclature. Chem. Geol., 29, 183-210.

Dixon, T.H., 1981. Age and chemical characteristics of some pre-African rocks in the Egyptian Shield. Precamb. Res., 14, 119-133.

Ekwere, S. J., 1985. Li, F and Rb contents and Ba/ $\mathrm{Rb}$ and $\mathrm{Rb} / \mathrm{Sr}$ ratios as indicators of post-magmatic alteration and mineralization in the granitic rocks of the Banke and Ririwai younger granite complexes, North Nigeria. Ear. Environ. Sci., 20, 89-93.

El-Bayoumi, R.M., 1980. Ophiolites and associated rocks of Wadi Ghadir, east of Gabal Zabara, Eastern Desert, Egypt. Ph.D. Thesis, Cairo Univ., Egypt, 171p.

El-Gaby, S., 1975. Petrochemistry of some granites from Egypt. N. Jb. Mineral. Abh., 124, 147189.

El-Galy, M.M., 1998. Geology, radioactivity, geochemistry and tectonic setting of selected granitic rocks, West Gulf of Aqaba, Sinai, Egypt. 
Ph.D Thesis, Tanta Univ., Egypt. 324 p.

El-Manharawy, M.S., 1977. Geochronological investigation of some basement rocks in Central Eastern Desert, Egypt between Lat. $25^{\circ}$ and $26^{\circ} \mathrm{N}$ [D]. Unpub. Ph.D. Thesis, Cairo Univ., Egypt, 216 p.

El-Ramly, M.F., and Akaad, M.K., 1960. The basement complex in the central Eastern Desert of Egypt between lat. $24^{\circ} 30^{\prime}$ and $25^{\circ} 40^{\prime} \mathrm{N}$. Geol. Surv. Egy., 6, 19 p.

El-Sharkawy, M.A., and El-Bayoumi, R.M., 1979. The ophiolites of Wadi Ghadir area, Eastern Desert. Ann. Geol. Surv. Egy., 9, 125-134.

El-Shazly, E.M., 1964. On the classification of the Precambrian and other rocks of magmatic affiliation in Egypt. $22^{\text {rd }}$ Inter. Geol. Congr. Proc. Sect., 10, India, 88-101.

Faure, G., 1986. Principles of isotope geology. John Wiley \& Sons, inc., New York, 889p.

Gifkins, C.C., and Allen, R.L., 2001. Textural and chemical characteristics of diagenetic and hydrothermal alteration in glassy volcanic rocks: Examples from the Mount Read volcanics, Tasmania. Econ. Geol., 96, 973-1002.

Hashad, A.H., 1980. Present status of geochronological data on the Egyptian basement complex. Instit. Appl. Geol. Bull., Jeddah, 4, 31-46.

Hassan, M.A., and Hashad, A.A., 1990. Precambrian of Egypt. 201-245 In: The Geology of Egypt (Said, R.,Ed.). Balkema, Rotterdam, 722 p.

Hume, W.F., 1935. Geology of Egypt. Vol. 2, Part 2. The later plutonic and intrusive rocks. Geol. Surv. Egypt. Government press, Cairo, 301688.

Hussein, A.A.; Aly, M.M., and El-Ramly, M.F., 1982. A proposed new classification of the granite of Egypt. J. Volcanol. Geotherm. Res., 14, 187-198.

Ibrahim, I.H., and Ali, M.A., 2003. The granitic rocks in Wadi Ghadir area, South Eastern Desert, Egypt and occurrence of a secondary ura- nium mineral. Egy. J. Geol., 47(2), 671- 687.

Ishikawa, Y.; Sawagushi, T.; Jwaya, S., and Horiuchi, M., 1976. Delineation of prospecting targets for Kuroko deposits based on modes of volcanism of underlying dacite and alteration holes. Mining Geol., 26, 105-117. (in Japanese with English abs.).

Jensen, B.B., 1967. Distribution patterns of rare earth elements in cerium-rich minerals. Nor. Geol. Tidsskr., 47, 9-19.

Kamar, M.S., 2014. Geochemistry and mineralizations of the Wadi Ghadir younger granites and associated pegmatites, South Eastern Desert, Egypt. Arab. J. Geosci., 8, No. 3, 1315-1338

Kröner, A.; Todt, W.; Hussein, I.M.; Mansour, M., and Rashwan, A.A., 1992. Dating of late Proterozoic ophiolites in Egypt and the Sudan using the single grain zircon evaporation technique. Prec. Res., 59, 15 -32.

Large, R.R.; Gemmell, J.B., and Paulik, H., 2001. The alteration Box Plot: A simple approach to understanding the relationship between alteration mineralogy and lithogeochemistry associated with volcanic-hosted massive sulfide deposits. Econ. Geol., 96, 957-971.

Le Maitre, R.W.; Bateman, P.; Dubek, A.; Keller, J.; Lameyre, J.; Le Bas, M.J.; Sabine, M.A.; Schmid, R.; Wooley, A.R., and Zanettin, B., 1989. A classification of igneous rocks and glossary of terms: Recommendations of the International Union of Geological sciences subcommisson on the systematics of igneous rocks. Oxford, Black-well Scientific publications, 193p.

Luth, W.C.; Jams, R.H., and Tuttle, O.F., 1964. The granite system at pressure of 4 to 10 kilobars. J. Geophys. Res., 69, 759-773.

Meyer, C.H., and Hemley, T.T., 1967. Wall rock alteration. In: Geochemistry of hydrothermal ore deposits (Barnes, H.G.,Ed.). Holt, Rinehart Winston, York, 166-235.

Nadaa, A., and Aly, H.A.S., 2014. The effect of 
uranium migration on radionuclide distributions for soil samples at the El-Gor area, Sinai, Egypt. Appl. Radiat. Isotopes., 84, 79-86.

O'Connor, J.T., 1965. Classification of quartz-rich igneous rocks based on feldspar ratio. U.S. Geol. Surv. Prof. Paper 525-B, B-79, B-84.

Pabst, A., and Hutton, C.O., 1951. Huttonite, a new monoclinic thorium silicate. Am. Mineral., $36,60-69$.

Pearce, J.A; Harris, N.B.W., and Tindle, A.G., 1984. Trace element discrimination diagrams for the tectonic interpretation of granitic rocks. J. Petrol., 25, 956-983

Raslan, M.F., and El-Feky, M.G., 2012. Radioactivity and mineralogy of the altered granites of the Wadi Ghadir shear zone, South Eastern Desert, Egypt. Chin. J. Geochem., 31 (1), 30- 40.

Stern, R.J., and Hedge, C.E., 1985. Geochronological and isotopic constraints on Late Precambrian crustal evolution in the Eastern Desert of Egypt. Am. J. Sci., 285, 97-127.

Surour, A.A.; El-Bayoumi, R.M.; Attawiya, M.Y., and El-Feky, M.G., 2001. Geochemistry of wall rock alterations and radioactive mineralization in the vicinity of Hangaliya auriferous shear zone, Eastern Desert, Egypt. J. Geol., 45(1), 187-212.

Takla, M.A.; Basta, F.F.; Shenouda, H.H., and ElMaghraby, A.M., 1992. Geochemistry of gneisses and granitoids of Wadi Ghadir area, Eastern Desert, Egypt., $1^{\text {th }}$ Int. Conf. Geol. Arab World, (GAW-I), Cairo Univ., Egypt, 477- 489.

Tuttle, O.F., and Bowen, N.L., 1958. The origin of granite in the light of experimental studies in the system $\mathrm{NaAlSi}_{3} \mathrm{O}_{8}-\mathrm{KAlSi}_{3} \mathrm{O}_{8}-\mathrm{SiO}_{2}-\mathrm{H}_{2} \mathrm{O}$. Geol. Soc. Am. Mem., 74, 153p.

Weaver, B., and Tarney, J., 1984. Empirical approach to estimating the composition of the continental crust. Nature, 310, 575-57.

Wood, D.A.; Tarney, J.; Varet, J.; Saunders, A.D.; Bougault, H.; Treuil, M., and Cann, J.R., 1979. Geochemistry of basalts drilled in the North Atlantic by IPOD Leg 49: implication for mantle heterogeneity. Earth Planet. Sci. Lett., 42, 7797.

Wright, J.B., 1969. A simple alkalinity ratio and its application to questions of Non-orogenic granite genesis. Geol. Mag., 106, 370-384.

$$
\begin{aligned}
& \text { جيولوجية، جيوكيميائية وإشعاعية صخور المونزوجرانيت، شمال وادى غدير، جنوب الصحراء الشرقية، } \\
& \text { فراج محمد خليل، محمد سالم قمر وأنس مالك الشريف } \\
& \text { يهاف هذا البحث المى دراسة صخور المونزوجرانيت وبعض الاجزاء المتغايرة فيه من الناحية الجيولوجية، الجيوكيميائية }
\end{aligned}
$$

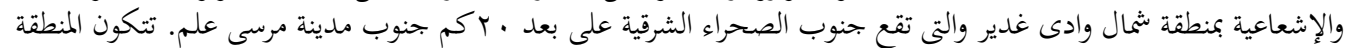

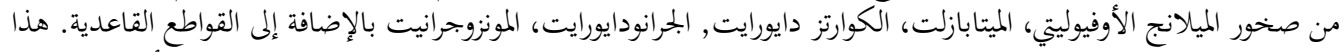

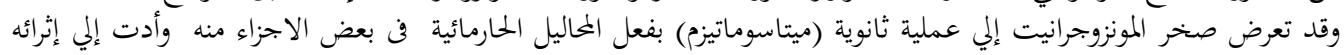

$$
\begin{aligned}
& \text { بمعدن البيريت. }
\end{aligned}
$$

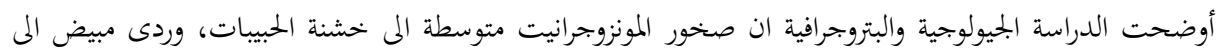

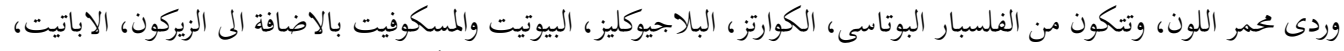

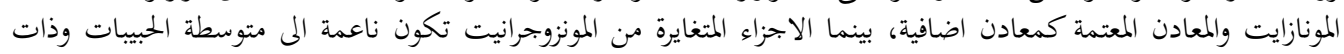

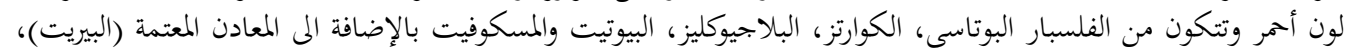

$$
\begin{aligned}
& \text { الاباتيت والتيتانايت كمعادن اضافية. }
\end{aligned}
$$




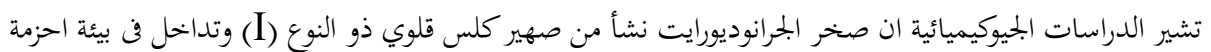

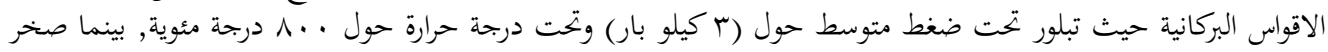

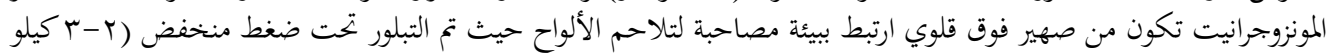

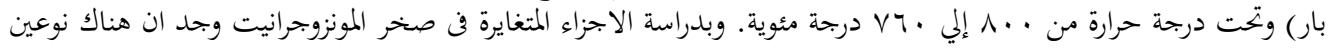

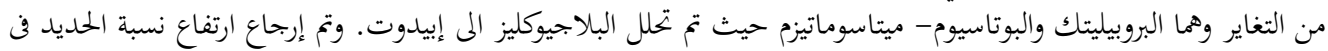

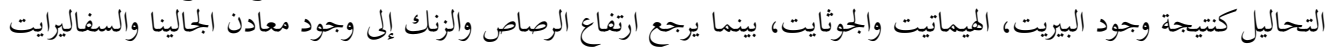
بالترتيب.

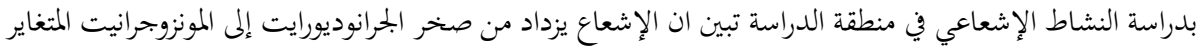

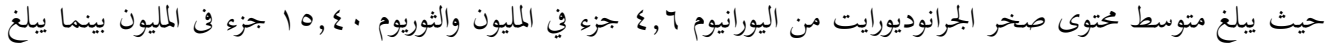

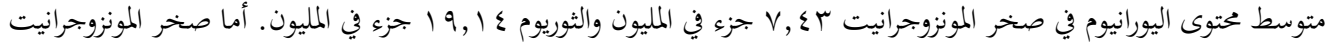

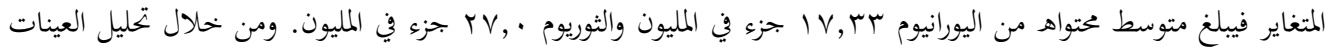

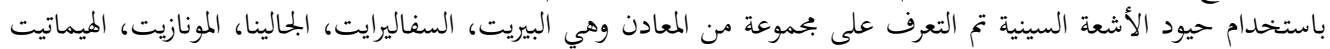
والجوثايت.

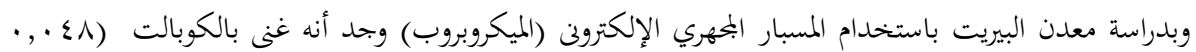

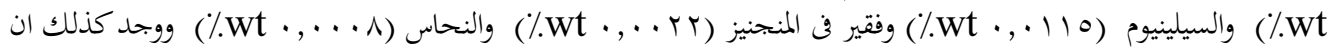

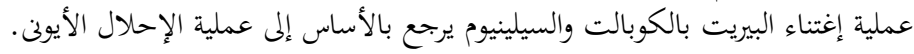

